\title{
Pollution investigation and risk assessment of polycyclic aromatic hydrocarbons in soil and water from selected dumpsite locations in rivers and Bayelsa State, Nigeria.
}

\author{
Victor Uchenna Okechukwu ${ }^{1}$ (D), Daniel Omeodisemi Omokpariola ${ }^{1, *(i)}$, Valentine Ifenna Onwukeme ${ }^{1}$, Eucheria \\ Nkiru Nweke ${ }^{1,2}$ (iD), Patrick Leonard Omokpariola ${ }^{3}$ (i) \\ ${ }^{1}$ Department of Pure and Industrial Chemistry, Nnamdi Azikiwe University, Awka, Nigeria. \\ ${ }^{2}$ Department of Chemistry, College of Education, Umunze, Nigeria. \\ ${ }^{3}$ Directorate of Chemical Evaluation and Research, National Agency for Food and Drug, Administration and Control, Isolo, \\ Nigeria. \\ *Correspondence: omeodisemi@gmail.com
}

Received: August 2, 2021 Accepted: September 27, 2021

\begin{abstract}
The transfer ratio of polycyclic aromatic hydrocarbons (PAHs) from soil dumpsite to borehole water is dependent of polluting source and exposure matrices that causes immerse health risk to man and environment over a period of time. PAHs were assessed in selected soil dumpsite and borehole water located at Rivers state (Eleme, Eliozu, Eneka, Oyigbo, and Woji) and Bayelsa state (Yenagoa), Nigeria. Soil samples were collected at four different points $30 \mathrm{~m}$ (North, South, East and West) locations at a depth of $15 \mathrm{~cm}$ for each dumpsite using soil auger while control samples were collected $200 \mathrm{~m}$ away (farmland), where there were little anthropogenic activities and no presence of active dumpsites. Borehole water samples were collected from $300 \mathrm{~m}$ distance, which were packaged in an amber container, labeled, and transported to the laboratory for analysis. Standard analytical methods were employed. PAHs concentrations were analyzed using gas chromatography- mass spectrometry (GC-MS) after extraction of water and soil using liquid-liquid and soxhlet extraction methods respectively and clean-up of the extracts, thereafter the laboratory data generated were subjected to statistical analysis. Total PAHs ( $\Sigma$ PAHS) concentrations in soil samples from the study sites ranged from $2.4294 \mathrm{mg} / \mathrm{kg}$ in Yenagoa to $5.1662 \mathrm{mg} / \mathrm{kg}$ in Eleme while in water samples the total PAHs ranged from $1.3935 \mathrm{mg} / \mathrm{L}$ in Woji to 3.009 $\mathrm{mg} / \mathrm{L}$ in Eleme. The total PAH concentrations in the soil were above the Agency for Toxic Substances and Disease Registry levels of $1.0 \mathrm{mg} / \mathrm{kg}$ for a considerably contaminated site except for the control sites. The total concentration of carcinogenic PAHs ranged from 0.0038 to $1.1301 \mathrm{mg} / \mathrm{kg}$ in soil samples and 0.0014 to $0.9429 \mathrm{mg} / \mathrm{L}$ in borehole water samples, therefore raising concern of human exposure via food chain. The results indicate that low molecular weight PAHs were more dominant than high molecular weight PAHs in both soil and water samples, however molecular diagnostic ratio shows that pyrogenic activities are major sources of PAHs as compared to petrogenic origin. Multivariate analysis (principal component analysis and Pearson correlation) showed strong negative correlation implying that they were from dissimilar sources and different migratory route. Cancer and non-cancer risk showed that children were more at risk compared to adults, where inhalation exposure were major contribution as compared to ingestion and dermal exposure, as such there is a need to implement regulatory laws on indiscriminate release of PAHs contaminants to maintain sustainability.
\end{abstract}

Keywords: PAHs contaminants, Soil dumpsite, Molecular diagnostic ratio, Cancer risk, Hazard index, Southern Nigeria

\section{Introduction}

Globally, there has been an increase in the amount of waste generated as a result of growing rate of industrialization, urbanization and population growth [1,2]. Studies have shown that excessive anthropogenic activities (which include gas flaring, fossil fuel combustion, oil spill and inappropriate disposal of industrial wastes) in the form of environmental pollution causes major harm to the environment leading to severe soil degradation, poor water quality and polluted atmosphere in relation to the aesthetic view [3,4]. In Nigeria, the desire to develop and carry out a long-term waste management plan based on public health principles has led to large number of open dumpsites that are not managed appropriately as these dumpsites are incinerated openly, thus leading to release of harmful chemical pollutants to the 
environment [5,6]. It is a known fact that poor management of waste dumpsites endangers the groundwater supply as infiltration of chemical leachates from dumpsites through the soil and the aquifers pose a risk to the environment and human health [7-9].

Polycyclic aromatic hydrocarbons, PAHs are cluster of organic compounds with two or more fused benzene rings in various structural configurations and do not contain hetero atom derived from the incomplete combustion of organic matters including coal, oil, gas, wood, garbage, or other organic substances, such as tobacco and charbroiled meat [10,11]. Primary sources of PAHs in the environment are mainly from the incomplete combustion of various organic matters such as fossil fuels (e.g., coal, gasoline, and diesel) and biomass fuels (e.g., straw, firewood), garbage, petroleum product spillage, various industrial, commercial, domestic and agricultural activities [12]. Due to the ubiquitous nature of PAHs, they are found in a wide range of environment including soils, sediments, ground waters, and the atmosphere. It is estimated that $90 \%$ of the total environmental PAHs load is found in terrestrial ecosystems, and more specifically, the top $20 \mathrm{~cm}$ of the soil horizon [11,13]. PAHs present in soil may exhibit a toxic activity towards different plants, microorganisms, and invertebrates [14,15]. Yang et al. [16] found soils as sink for large number of PAHs, as some of them pose threats to human health. PAHs are pollutants of great concern which are widespread in various ecosystems because of their potential toxicity to aquatic life as several PAHs components are suspected human carcinogens, mutagens, and endocrine disrupters [17-19].

The US Environmental Protection Agency has classified 16 PAHs as priority pollutants, eight of which are possible human carcinogens which include benz(a)anthracene, benzo(a)pyrene, benzo(b)fluoranthene, benzo(k)fluoranthene, chrysene, dibenz (a,h)anthracene, indeno(l,2,3-cd)pyrene [20,21]. The light PAHs (2-3 rings) such as naphthalene, fluorene, phenanthrene and anthracene have significant acute toxicity to aquatic organisms, while heavy PAHs (4-6 rings) such as chrysene and coronene do not but are carcinogenic [21]. According to USEPA, [22,23] human exposure of PAHs occurs via inhalation of particulate matter, dermal adsorption during contact to contaminated soil and water, and oral ingestion of soil and water. Oral ingestion can also result in tandem with inhalation of particulates from impaction onto mucus membrane in tracheobronchial tract, movement up the tract by cilia to pharynx, and swallowing [24,25]. Exposure of PAHs increases across large radius from close proximity index via leachate for water sources in respect to passer-by and people living within a given vicinity, where these wastes are present may be of greater exposure risk through inhalation due to constant burning of dumpsites [15,25,26].

Consequently, there is a need to assess the PAHs concentration with a mandate to enlighten public health expert, environmental policy makers and regulatory agencies on the relationship between health issues and environmental pollution over a given period. Therefore, the study aims to assess the concentrations and human health risk of PAHs in soils and water boreholes from the selected active waste dumpsites in Rivers and Bayelsa States, South-South Nigeria.

\section{Materials and Methods Description of study site}

In this study, six (6) major waste dumpsites, five (5) located in Rivers State (Eleme, Eliozu, Eneka, Oyigbo, Woji) and one (1) located in Bayelsa state (Yenagoa), South-South, Nigeria were selected as shown in Figure 1. The study site is characterized by tropical dry seasons (November to February) and wet seasons (March to October) with a mean annual rainfall increasing from $2000 \mathrm{~mm}$ around the northern border to about $4500 \mathrm{~mm}$ around the coastal margin [27]. The dumpsites are surrounded by residential houses, factories, gasoline stations, auto spare parts market and auto repair workshops as these expose residents, rag-pickers passer-by including infants to soil and water contaminants by inhalation, ingestion and dermal contacts. 


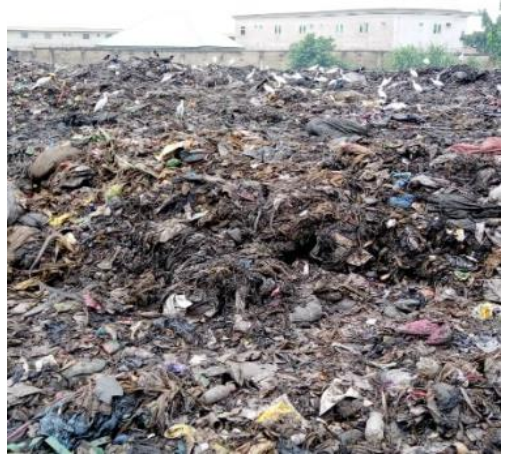

Eleme

Latitude: $04^{\circ} 79^{\prime} 94^{\prime \prime} \mathrm{N}$

Longitude: $06^{\circ} 54^{\prime} 48.7^{\prime \prime} \mathrm{E}$

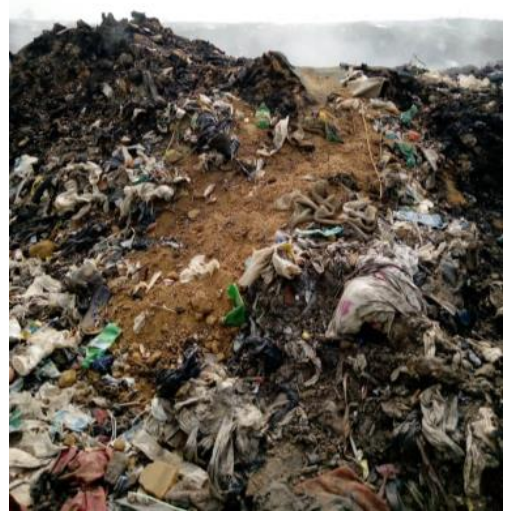

Oyigbo

Latitude: $04^{\circ} 53^{\prime} 07.4^{\prime \prime} \mathrm{N}$

Longitude: $07^{\circ} 00^{\prime} 50.1^{\prime \prime} \mathrm{E}$

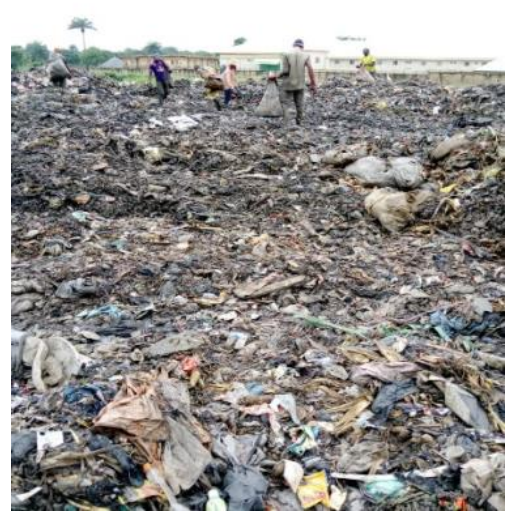

\section{Eliozu}

Latitude: $04^{\circ} 54^{\prime} 16.4^{\prime \prime} \mathrm{N}$

Longitude: $07^{\circ} 11^{\prime} 98^{\prime \prime}{ }^{\circ} \mathrm{E}$

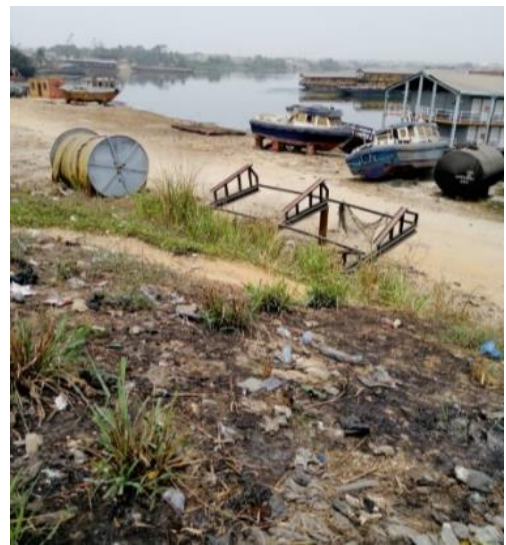

\section{Woji}

Latitude: $04^{\circ} 82^{\prime} 83^{\prime \prime} \mathrm{N}$

Longitude: $07^{\circ} 05^{\prime} 79^{\prime \prime} \mathrm{E}$

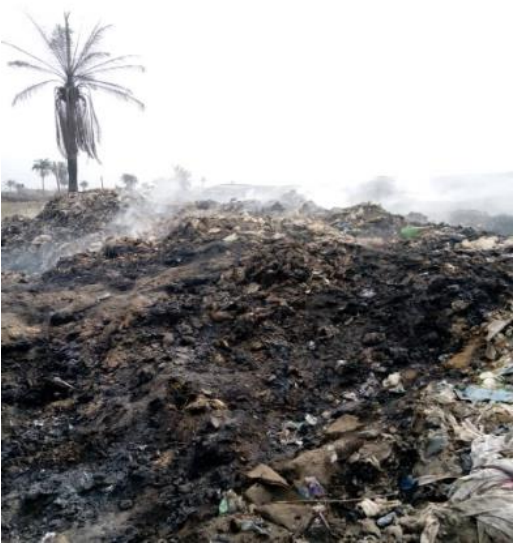

Eneka

Latitude: $04^{\circ} 53^{\prime} 34.1^{\prime \prime} \mathrm{N}$

Longitude: $06^{\circ} 54^{\prime} 48.7^{\prime \prime} \mathrm{E}$

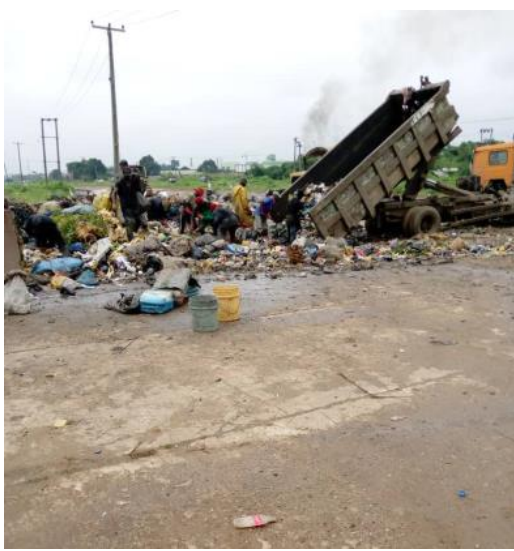

Yenagoa

Latitude: $\quad 04^{\circ} 58^{\prime} 59.20^{\prime \prime} \mathrm{N}$

Longitude: $06^{\circ} 19^{\prime} 18.2^{\prime \prime} \mathrm{E}$

Figure 1. Active waste dumpsites in Rivers and Bayelsa State, Nigeria [1].

\section{Sample collection of soil and water}

Soil samples were collected from selected dumpsites in a $30 \mathrm{~m}$ quadrant route (West, East, South and North) with soil auger and a spatula at a depth of $15 \mathrm{~cm}$ after removing the overlying wastes, while control site soil sampling was done at $200 \mathrm{~m}$ distance from the dumpsites that is a farmland with minimal human activity. The quadrant samples from each dumpsite were homogenized into a composite sample in tandem to the control site also. The composite soil samples were air-dried at room temperature for 48 hours before ground using a porcelain pestle and mortar to reduce the surface area and sieved with a $2 \mathrm{~mm}$ nylon mesh to give the fine earth fraction. The samples were stored in prelabeled polythene bags and were taken to the laboratory for further chemical evaluation.

Water samples were collected from borehole water source at $300 \mathrm{~m}$ proximity to an active waste dumpsite, which was done in four sample locations (Eleme, Eneka, Woji, and Control Site 1). The water was collected from four residential home equipped with installed borehole water system at close proximity to each other, which was thereafter mixed to form a composite sample into $500 \mathrm{~mL}$ sampling amber glass bottles. The samples were labeled, thereafter kept in a refrigerator pending laboratory analysis.

\section{Quality control process}

Sample blank solutions were prepared using the same procedure described for the samples. Same quantities of reagents were used for sample and blank. All reagents used were of analytical grade. The reliability and reproducibility of the measurements were ensured by calibrating the instruments used and procedural blanks determined. 


\section{Determination of polycyclic aromatic hydrocarbons (PAHs) in soil samples Soil PAHs extraction and clean-up}

The United States Environmental Agency, USEPA-8100 extraction method was used for the preparation of soil samples for analysis. $10 \mathrm{~g}$ of soil sample was measured out and quantitatively transferred into a $250 \mathrm{~mL}$ separating funnel. A $20 \mathrm{~mL}$ of Dichloromethane was added to the soil sample in the funnel and sonicated for $10-15$ minutes at about $70{ }^{\circ} \mathrm{C}$ (This was done in triplicates to extract all analyte present in the sample) [28]. After sonication, $10 \mathrm{~g}$ of anhydrous sodium Sulphate was added to the samples to remove any residual water molecules. This was allowed to stand for about 10-15 minutes. It was then set to shake continuously for 30 minutes at 300 minutes and finally allowed to stand for 5 minutes to sufficiently separate the phases. A $10 \mathrm{~mL}$ of the supernatant was carefully taken and dried over $2 \mathrm{~g}$ anhydrous magnesium sulphate through filter paper into $50 \mathrm{~mL}$ round bottom flask. This was then concentrated to about $2 \mathrm{~mL}$ using the rotary evaporator and made ready for silica clean up step. The clean-up was done according to method described by USEPA [28].

\section{Soil PAHs determination using gas chromatography/mass spectrometry}

The final extracts were analyzed by gas chromatograph- agilent HP 5890 series II model equipped with auto sampler and Ni electron capture detector (ECD) that allowed the detection of contaminants even at trace level concentrations (in the lower $\mu \mathrm{g} / \mathrm{g}$ and $\mu \mathrm{g} / \mathrm{kg}$ range) from the matrix to which other detectors do not respond. The GC conditions used for the analysis were capillary column coated with VF-5 (30 m + $10 \mathrm{~m}$ EZ guard column $x 0.25 \mathrm{~mm}$ internal diameter, $0.25 \mu \mathrm{m}$ film thickness). The injector and detector temperature were set at $250{ }^{\circ} \mathrm{C}$ and $300{ }^{\circ} \mathrm{C}$ respectively. The oven temperature was programmed as follows: $60^{\circ} \mathrm{C}$ held for $2 \mathrm{~min}$, ramp at $25^{\circ} \mathrm{C} / \mathrm{min}$ to $180{ }^{\circ} \mathrm{C}$, held for $1 \mathrm{~min}$, and finally ramp at $5{ }^{\circ} \mathrm{C} / \mathrm{min}$ to $31{ }^{\circ} \mathrm{C}$. Helium was used as carrier gas at constant flow rate of $1: 4^{\circ} \mathrm{C} / \mathrm{min}$ and detector make-up gas of $29 \mathrm{~mL} / \mathrm{min}$. The injection volume of the GC was $1.5 \mathrm{~mL}$ with total run time for each sample was $31.4 \mathrm{~min}$. Results obtained were presented as $\mathrm{mg} / \mathrm{kg}$ concentration per analyte.

$$
\text { PAHs concentration }(\mathrm{mg} / \mathrm{kg})=\frac{\text { Concentration }(\mathrm{mg} / \mathrm{kg}) \times \quad \text { Final volume }(1.5 \mathrm{~mL})}{\text { Sample weight }(10 \mathrm{~g})}
$$

\section{Determination of polycyclic aromatic hydrocarbons (PAHs) in water samples Extraction of PAHs from water samples}

The United States Environmental Protection Agency (USEPA) Method 3510 for aqueous matrix for the analysis of semi-volatile and non-volatile organics was modeled [28]. After filtration, $100 \mathrm{~mL}$ portion of the water sample was transferred into a $2 \mathrm{~L}$ capacity glass-separating funnel. Then $30 \mathrm{~mL}$ of saturated sodium chloride $(\mathrm{NaCl})$ was added to produce a salt out effect. It was thoroughly mixed by inverting the flask three to four times. $100 \mathrm{~mL}$ of dichloromethane as extraction solvent was added and this was vigorously shaken manually for 2-3 minutes and releasing the pressure at irregular intervals. The phases were then allowed to separate for 5 minutes, and the dichloromethane extract (upper organic layer) was collected from the aqueous layer in a round bottom flask. The extraction was repeated with $100 \mathrm{~mL}$ of dichloromethane and the organic layers were put together and dried over anhydrous magnesium sulphate. The extracts from water samples were then concentrated on rotary vacuum evaporator to about $2 \mathrm{~mL}$ and subjected to clean up.

\section{Water PAHs determination using gas chromatography/mass spectrometry}

One gram of silica gel that previously had been activated at $130{ }^{\circ} \mathrm{C}$ for 10 hours was carefully packed into $10 \mathrm{~mL}$ polypropylene cartridge column and $6 \mathrm{~mL}$ Dichloromethane was used to condition the cartridge. The concentrated extract was then loaded onto the column and $50 \mathrm{~mL}$ pear shape flask was placed under the column to collect the eluate. A $10 \mathrm{~mL}$ dichloromethane was used to elute the column afterwards, and the total filtrate collected concentrated to just dryness using the rotary evaporator set at $38^{\circ} \mathrm{C}$. The residue was re-dissolved in $1 \mathrm{~mL}$ methanol and transferred into a $2 \mathrm{~mL}$ standard vial prior to quantification by gas chromatography. The GC conditions used for the analysis were capillary column coated with VF-5 (30 m + $10 \mathrm{~m}$ EZ guard column $\times 0.25 \mathrm{~mm}$ internal diameter, $0.25 \mu \mathrm{m}$ film thickness). The injector and detector temperature were set at $250{ }^{\circ} \mathrm{C}$ and $300{ }^{\circ} \mathrm{C}$ respectively. The oven temperature was programmed as follows: $60{ }^{\circ} \mathrm{C}$ held for $2 \mathrm{~min}$, ramp at $25^{\circ} \mathrm{C} / \mathrm{min}$ to $180^{\circ} \mathrm{C}$, held for $1 \mathrm{~min}$, and finally ramp at $5^{\circ} \mathrm{C} / \mathrm{min}$ to $310^{\circ} \mathrm{C}$. Helium was used as carrier gas at a flow rate of $1: 4{ }^{\circ} \mathrm{C} / \mathrm{min}$, Inlet Mode: Splitless, Linear velocity: $30 \mathrm{~cm} / \mathrm{sec}$ and detector make-up gas of $29 \mathrm{~mL} / \mathrm{min}$. Results obtained were presented as $\mathrm{mg} / \mathrm{L}$ concentration per analyte.

$$
\text { PAHs concentration }(\mathrm{mg} / \mathrm{L})=\frac{\text { Concentration }(\mathrm{mg} / \mathrm{L}) \times \quad \text { Final volume }(1.5 \mathrm{~mL})}{\text { Sample weight }(100 \mathrm{~mL})}
$$




\section{Statistical analysis}

Laboratory data attained from soil and water samples were subjected to analysis Microsoft Excel 2016 software to determine mean \pm standard deviation (SD), multivariate analysis (principal component analysis, pearson correlation) was done to derive useful information on soil to water interaction across sample locations.

\section{Health and exposure risk assessment model}

Health and exposure risk assessment was determined using the United States Environmental Agency's risk models that assesses the health implication of PAHs exposure to humans (adults and children) across different exposure medium that is ingestion, dermal and inhalation accordingly. The risk assessment model utilized chronic daily intake (CDI) calculation of carcinogenic and non-carcinogenic PAHs via diverse exposure medium as shown below [29,30].

\section{Chronic daily intake of soil sample}

$$
\begin{aligned}
& \mathrm{CDI}-\text { ingestion }(\mathrm{mg} / \mathrm{kg} / \text { day })=\left(\frac{\mathrm{CS} \times \mathrm{IRS} \times \frac{10^{-6} \mathrm{~kg}}{\mathrm{mg}} \times \mathrm{EF} \times \mathrm{ED} \times \mathrm{RBA}}{\mathrm{THQ}^{* *} \times \mathrm{BW} \times \mathrm{AT} \times \mathrm{TR}^{*}}\right) \\
& \mathrm{CDI}-\text { dermal }(\mathrm{mg} / \mathrm{kg} / \text { day })=\left(\frac{\mathrm{CS} \times \mathrm{SA} \times \mathrm{AF} \times \mathrm{ABS}_{\mathrm{sk}} \times 10^{-6} \mathrm{~kg} / \mathrm{mg} \times \mathrm{EF} \times \mathrm{ED}}{\mathrm{BW} \times \mathrm{AT} \times \mathrm{THQ}^{* *} \times \mathrm{GIABS} \times \mathrm{TR}{ }^{*}}\right) \\
& \mathrm{CDI}-\text { inhalation }\left(\mathrm{mg} / \mathrm{m}^{3}\right)=\left(\frac{\mathrm{CS} \times \frac{1}{\mathrm{VF}} \times \frac{1}{\mathrm{PEF}} \times \mathrm{EF} \times \mathrm{ET}_{\mathrm{ih}} \times \frac{1 \mathrm{day}}{24 \mathrm{hr}} \times \mathrm{ED} \times 10^{6} \mathrm{~kg} / \mathrm{mg}^{*}}{\mathrm{AT} \times \mathrm{THQ}^{* *} \times \mathrm{TR}^{*}}\right)
\end{aligned}
$$

where CS is PAHs concentration in dumpsite soil (mg/kg), IRs is soil ingestion rate (mg/day) (100 mg/day for adults and $200 \mathrm{mg} /$ day for children), EF is exposure frequency (350-day year-1), ED is exposure duration (26 years for adults and 6 years for children), $\mathrm{TR}^{*}$ is target risk $(1 \times 10-6 \mathrm{mg} / \mathrm{mg})$ for carcinogen calculation only, $\mathrm{THQ}^{* *}$ : target hazard quotient $0.1 \mathrm{for}$ non-carcinogen calculation only, BW is body weight ( $80 \mathrm{~kg}$ for adults and $15 \mathrm{~kg}$ for children), AT is average time (noncarcinogens $=\mathrm{ED} \times 365$ days), $($ carcinogen $=70 \times 365)$, SA is skin surface area $\left(6032 \mathrm{~cm}^{2} /\right.$ day for adults and $2373 \mathrm{~cm}^{2} /$ day for children), AF is water adherence factor: $\left(0.2 \mathrm{mgcm}^{-2}\right.$ for adults and $0.07 \mathrm{mgcm}^{-2}$ for children), $\mathrm{ABS}_{\mathrm{sk}}$ is fraction of chemical absorbed through the skin (unit-less) ( 0.13 for adults and children), GIABS is fraction of contaminant absorbed in gastrointestinal tracts (unit-less) (1.0 for adults and children), ET ih is Exposure time ( $9 \mathrm{hrs} /$ days for adults and $6 \mathrm{hrs} / \mathrm{day}$ for children), VF is Volatilization factor $\left(0.00001 \mathrm{~m}^{3} / \mathrm{kg}\right.$ for adults and children) for non-carcinogen calculation; 0.006 for carcinogen calculation, PEF is Particulate emission factor $\left(1.36 \times 10^{9} \mathrm{~m}^{3} / \mathrm{kg}\right.$ for adults and children $), 10^{6 *} \mathrm{~kg} / \mathrm{mg}$ for carcinogen calculation only.

\section{Chronic daily intake of water}

$$
\begin{aligned}
& \mathrm{CDI}-\text { ingestion }(\mathrm{mg} / \mathrm{kg} / \text { day })=\left(\frac{\mathrm{CS} \times \mathrm{IRW} \times \mathrm{EF} \times \mathrm{ED} \times \mathrm{TF} \times \mathrm{THQ}^{*}}{\mathrm{BW} \times \mathrm{AT}}\right) \\
& C D I-\text { dermal }(\mathrm{mg} / \mathrm{kg} / \text { day })=\left(\frac{C S \times S A \times A F \times A B S_{S k} \times E T_{W} \times E F \times E D \times T F \times T H Q^{*}}{B W \times A T}\right)
\end{aligned}
$$

where CS is PAHS concentration in water $(\mathrm{mg} / \mathrm{L}), \mathrm{IRw}$ is daily water ingestion rate (L/day) (2.5 L/day for adults and 0.78 $\mathrm{L} /$ day for children), EF is exposure frequency (350-day year-1), ED is exposure duration (26 years for adults and 6 years for children), TF is target risk $\left(1 \times 10^{-6} \mathrm{mg} / \mathrm{mg}\right)$ for carcinogen, THQ ${ }^{*}$ : target hazard quotient 10 for non-carcinogen calculation only, BW is body weight ( $80 \mathrm{~kg}$ for adults and $15 \mathrm{~kg}$ for children), AT is average time (non-carcinogens $=$ ED $\times 365 \mathrm{days}$ ), (carcinogen $=70 \times 365)$, SA is skin surface area $\left(19652 \mathrm{~cm}^{2}\right.$ for adults and $6365 \mathrm{~cm}^{2}$ for children), AF is water adherence: $(0.2$ $\mathrm{mgcm}^{-2}$ for adults and children), $\mathrm{ABS}_{\mathrm{sk}}$ is fraction of chemical absorbed through the skin (unit-less) (0.001 for adults and children), $\mathrm{ET}_{\mathrm{w}}$ is exposure time during work event (1 h/event for adults and children).

\section{Carcinogenic risk assessment}

$$
\text { Cancer } \text { risk }_{\text {total }}=\text { Risk }_{i n g}+\operatorname{Risk}_{d e r}+\operatorname{Risk}_{i n h}=([\mathrm{CDI}(\mathrm{Ing}) \times \mathrm{OSF}]+[\mathrm{CDI}(\text { der }) \times \mathrm{CSF}]+[\mathrm{CDI}(\mathrm{Inh}) \times \mathrm{IUR}])
$$

where cancer risk is the possibility of an adult or child developing cancer over a lifetime, CDI (E) is the chronic daily intake for any exposure matrix (ingestion, dermal and inhalation), CSF is cancer slope factor of PAHs (mg/kg/day) ${ }^{-1}$, OSF is oral slope factor $(\mathrm{mg} / \mathrm{kg} / \text { day })^{-1}$, IUR is inhalation unit risk $\left(\mathrm{mg} / \mathrm{m}^{3}\right)^{-1}$. 


\section{Non-carcinogenic risk assessment}

$$
\mathrm{HI}=\mathrm{HQ}_{\text {ing }}+\mathrm{HQ}_{\text {der }}+\mathrm{HQ}_{\text {inh }}=\left(\left[\frac{\mathrm{CDI}(\mathrm{ing})}{\mathrm{RfD}}\right]+\left[\frac{\mathrm{CDI}(\text { Der })}{\mathrm{RfD}}\right]+\left[\frac{\mathrm{CDI}(\mathrm{inh})}{\mathrm{RfC}}\right]\right)
$$

where $\mathrm{HI}$ is hazard index that is the sum of all hazard quotient (HQ) of multiple exposure pathway, HQ is probable condition that can lead to adverse health effect, $\mathrm{CDI}(\mathrm{E})$ is the chronic daily intake for any exposure matrix, RfD is reference dose $\left(\mathrm{mg} / \mathrm{kg} /\right.$ day), RfC is reference inhalation constant $\left(\mathrm{mg} / \mathrm{m}^{3}\right)$.

The reference table for carcinogenic and non-carcinogenic risk assessment are presented in Table 1.

Table 1. Reference value for polycyclic aromatic hydrocarbons (PAHs)

\begin{tabular}{lllllll}
\hline PAHs & $\begin{array}{l}\text { Ingestion } \\
\text { OSF }\end{array}$ & RfD & CSF & RfD & IUR & RfC \\
\hline Naphthalene (Nap) & NA & 0.04 & NA & $0.02^{* *}$ & 0.034 & 0.003 \\
Acenaphthene (Ace) & $0.073^{*}$ & 0.006 & $0.073^{*}$ & $0.02^{* *}$ & $0.011^{*}$ & $0.88^{* *}$ \\
Acenaphthylene (Acy) & $0.0073^{*}$ & 0.06 & $0.0073^{*}$ & $0.06^{* *}$ & $0.0011^{*}$ & $0.88^{* *}$ \\
Fluorene (Flu) & $\mathrm{NA}$ & 0.04 & $\mathrm{NA}$ & $0.04^{* *}$ & $\mathrm{NA}$ & $\mathrm{NA}$ \\
Phenanthrene (Phen) & $\mathrm{NA}$ & 0.04 & $\mathrm{NA}$ & $\mathrm{NA}$ & $\mathrm{NA}$ & $\mathrm{NA}$ \\
Anthracene (Ant) & $\mathrm{NA}$ & 0.3 & $\mathrm{NA}$ & $0.3^{* *}$ & $\mathrm{NA}$ & $\mathrm{NA}$ \\
Fluoranthene (Flt) & $0.073^{*}$ & 0.04 & $0.073^{*}$ & $0.04^{* *}$ & $0.011^{*}$ & $0.88^{* *}$ \\
Pyrene (Pyr) & $0.73^{*}$ & 0.03 & $0.73^{*}$ & $0.03^{* *}$ & $0.11^{*}$ & $0.88^{* *}$ \\
Benzo[a]anthracene (BaA) & $0.73^{*}$ & 0.03 & $0.73^{*}$ & $0.03^{* *}$ & $0.11^{*}$ & $0.88^{* *}$ \\
Chrysene (Cry) & $0.0073^{*}$ & 0.03 & $0.0073^{*}$ & $0.03^{* *}$ & $0.0011^{*}$ & $0.88^{* *}$ \\
Benzo[b]fluoranthene (BbF) & $0.73^{*}$ & 0.03 & $0.73^{*}$ & $0.03^{* *}$ & $0.11^{*}$ & $0.88^{* *}$ \\
Benzo[k]fluoranthene (BkF) & $0.0073^{*}$ & 0.03 & $0.0073^{*}$ & $0.03^{* *}$ & $0.011^{*}$ & $0.88^{* *}$ \\
Benzo[a]pyrene (BaP) & $7.3^{*}$ & 0.03 & $7.3^{*}$ & $0.03^{* *}$ & $1.1^{*}$ & $0.88^{* *}$ \\
Dibenzo[a,h]anthracene (DBA) & $7.3^{*}$ & 0.03 & $7.3^{*}$ & $0.03^{* *}$ & $1.2^{*}$ & $0.88^{* *}$ \\
Indeno[1,2,3-cd] pyrene (IND) & $0.73^{* *}$ & 0.03 & $0.73^{*}$ & $0.03^{* *}$ & $0.11^{*}$ & $0.88^{* *}$ \\
Benzo[ghi]perylene (BghiP) & $0.073^{*}$ & 0.03 & $0.073^{*}$ & $0.03^{* *}$ & $0.011^{*}$ & $0.88^{* *}$ \\
\hline
\end{tabular}

${ }^{*}[31,32],{ }^{* *}[29,33]$. CSF: cancer slope factor $\left(\mathrm{mg} / \mathrm{kg} /\right.$ day), OSF: oral slope factor $\left(\mathrm{mg} / \mathrm{kg} /\right.$ day), IUR: inhalation unit risk $\left(\mathrm{mg} / \mathrm{m}^{3}\right), \mathrm{RfD}:$ reference dose, RfC: reference concentration.

\section{Results and Discussion \\ PAHs composition in soil dumpsites}

Figures 2 and 3 show the percentage stark column of PAHs in soil dumpsite and borehole water. As we can see in soil dumpsite (Figure 2), there was presence of naphthalene, acenaphthene, fluorene, benzo(k)fluoranthene in all locations, while pyrene, dibenzo(a,h)anthracene, indeno(1,2,3-cd) pyrene and benzo(g,h,i)perylene) were absent accordingly. Phenanthrene was present in Eleme, Eneka, Yenagoa, while absent in Eliozu, Oyigbo, Woji, control site 1 and 2, while for acenaphthylene was absent in control site 2 and present in all locations. In decreasing order, the cumulative PAHs concentration showed that Eleme $>$ Oyigbo $>$ Eliozu $>$ Woji $>$ Eneka $>$ Yenagoa $>$ control site $1>$ control site 2 (Figure 3) depict presence of 16 PAHs components except benzo(b)fluoranthene, benzo(k)fluoranthene, benzo(a)pyrene, indeno(1,2,3$\mathrm{cd})$ pyrene and benzo(g,h,i)perylene respectively. A review on the percentage stark column showed that Eleme contributed a commemorate PAHs concentration in comparison to other locations (Eneka, Woji and control site 1).

The results of the concentrations of polycyclic aromatic hydrocarbons (PAHs) for soil and borehole water matrix are presented in Tables 2 and 3, respectively. Twelve and eleven PAHs were detected out of the sixteen priority PAHs analyzed in the soil and borehole water respectively with varying concentration from one location to the other. These PAHs include naphthalene, acenaphthylene, acenaphthene, fluorene, phenanthrene, anthracene, fluoranthene, benzo(a)anthracene, chrysene, benzo(b)fluoranthene, benzo(k)fluoranthene, benzo(a) pyrene and dibenz(a,h)anthracene . The four PAHs that were not detected in the soil samples were benzo(ghi)perylene, dibenzo(a,h)anthracene, pyrene and indeno(1,2,3-cd)pyrene while five PAHs were not detected in the water samples which include Benzo(b)fluoranthene, benzo(k)fluoranthene, benzo(a)anthracene, benzo(ghi)perylene and indeno(1,2,3-cd)pyrene. The total PAHs concentrations found in the soil ranged from 0.1049 to $5.1662 \mathrm{mg} / \mathrm{kg}$ (Table 2) while the total PAHs found in the borehole water ranged from 0.1060 to $3.009 \mathrm{mg} / \mathrm{L}$ (Table 3). The highest PAHs concentration in the soil $(5.1662 \mathrm{mg} / \mathrm{kg}$ ) was detected in soil samples 
located at Eleme dumpsite. Naphthalene $(1.8751 \pm 0.0003 \mathrm{mg} / \mathrm{kg})$ and acenaphthylene $(0.7706 \pm 0.0002 \mathrm{mg} / \mathrm{kg})$ were found in highest concentration at Eleme dumpsite. The highest PAHs concentration in borehole water samples (3.009 mg/kg) was detected in the bore water located at Eleme area. The occurrence of high levels of PAHs in this study area has negative impacts on humans living within the vicinity the area. The high concentration of PAHs observed at Eleme dumpsite in this study could be as a result of open burning and oil /petrochemical industries located in Eleme which discharge their wastes at these dumpsites. According to Mohammed et al. [34], municipal waste and waste discharge from industrial sites are part of the factors causing a high concentration of PAHs in dumpsites soil. The lowest concentration $(0.1060) \mathrm{mg} / \mathrm{kg}$ was detected in the control sample located far away from the dumpsites and industrial activities. The accumulation of PAHs in all soil samples followed the order; Eleme $>$ Oyigbo $>$ Eliozu $>$ Woji $>$ Eneka $>$ Yenagoa dumpsite while the accumulation of PAHs in all the borehole water samples followed the order; Eleme $>$ Eneka $>$ Woji locations.

Generally, higher molecular weight (HMW) PAHs display considerable propensity than the lower molecular weight PAHs (LMW) and remain sorbed to soils rather than remain in the water or air and in addition have the greater capacity to bio-accumulate in organisms. In the present study, the distribution of low molecular weight (LMW) PAHs and high molecular weight (HMW) PAHs in the soil and borehole water samples (Tables 2 and 3) shows that $\Sigma$ LMW are the dominant in the dumpsite soils and the borehole water. The dominance of the low molecular weight PAHs in this study suggests a recent release of PAHs to the environment from different sources due to the LMW PAHs are more biodegradable, less lipophilic and are not to be sorbed as strongly as the HMW PAHs [35]. The presence of low molecular weight PAHs in the environment usually results from the emission of oil spills, domestic coal burning and noncombustible matter, while high molecular weight PAHs results from emission of incomplete combustion of organic matter and solid wastes and industrial plants emission [36].The results were similar to study carried out by Ekpete et al. [37] and Mohammed et al. [34] to determine the concentration of PAHs from selected dumpsites within Port Harcourt metropolis, where they attributed the dominance of 2-3 membered rings in majority of the dumpsites and concentrations of leachates from a popular dumpsite in Lagos state respectively, but was not in agreement to the result of Adedosu et al. [36] in Balogun-Biro dumpsite, Nigeria where high molecular weight PAHs dominants to the low molecular weight PAHs.

The total PAHs concentrations in the soil across the study area were observed to be above the Agency for Toxic Substances and Disease Registry levels of $1.0 \mathrm{mg} / \mathrm{kg}$ for a significantly contaminated site, due to the total PAHs concentration across the study areas was within 1 and $10 \mathrm{mg} / \mathrm{kg}$, since levels of the total of PAHs between 0.0 and $0.1 \mathrm{mg} / \mathrm{kg}$ are considered as non-contamination, values that fall between 0.1 and $1 \mathrm{mg} / \mathrm{kg}$ indicates slight contamination, while values between 1 and $10 \mathrm{mg} / \mathrm{kg}$ are indication of significant contamination [20,38]. When comparing the total concentration of PAHs in the dumpsites soil of this study, it was found that the values were similar to the report in Balogun-Biro dumpsite, Nigeria $(5.6491 \mathrm{mg} / \mathrm{g}$ ) [36] but lower than the values reported in Sapele municipality, Nigeria $(584.44 \mu \mathrm{g} / \mathrm{g})$ [39]. When comparing the total concentration of PAHs in the borehole water of this study, it was observed that the values recorded were higher than the report of Elelenwo River at different stations $(0.230 \pm 0.037 \mathrm{mg} / \mathrm{L})$ [40], but lower to the report of Edori and Iyama [41] in the coastline areas of the new Calabar River at the effluents discharge point) and study in the Niger Delta area $(1.96$ to $10.9 \mu \mathrm{g} / \mathrm{L})$ by Anyakora and Herbert [42]. The values of PAHs observed in the different borehole water samples were lower than the acceptable limit of $10 \mathrm{mg} / \mathrm{L}$ stipulated by Federal ministry of environment for drinking water [43]. Although, the values were lower than the above acceptable limit, people living within the area stand the risk of being affected by the PAHs, hence, posing great health challenges [44]. From observation of the results, incomplete combustion of waste at the studied dumpsites, presence of chemical and petrochemical industries using power generating plants within the studied area, may have contributed to the quantity of PAHs observed in the different dumpsites.

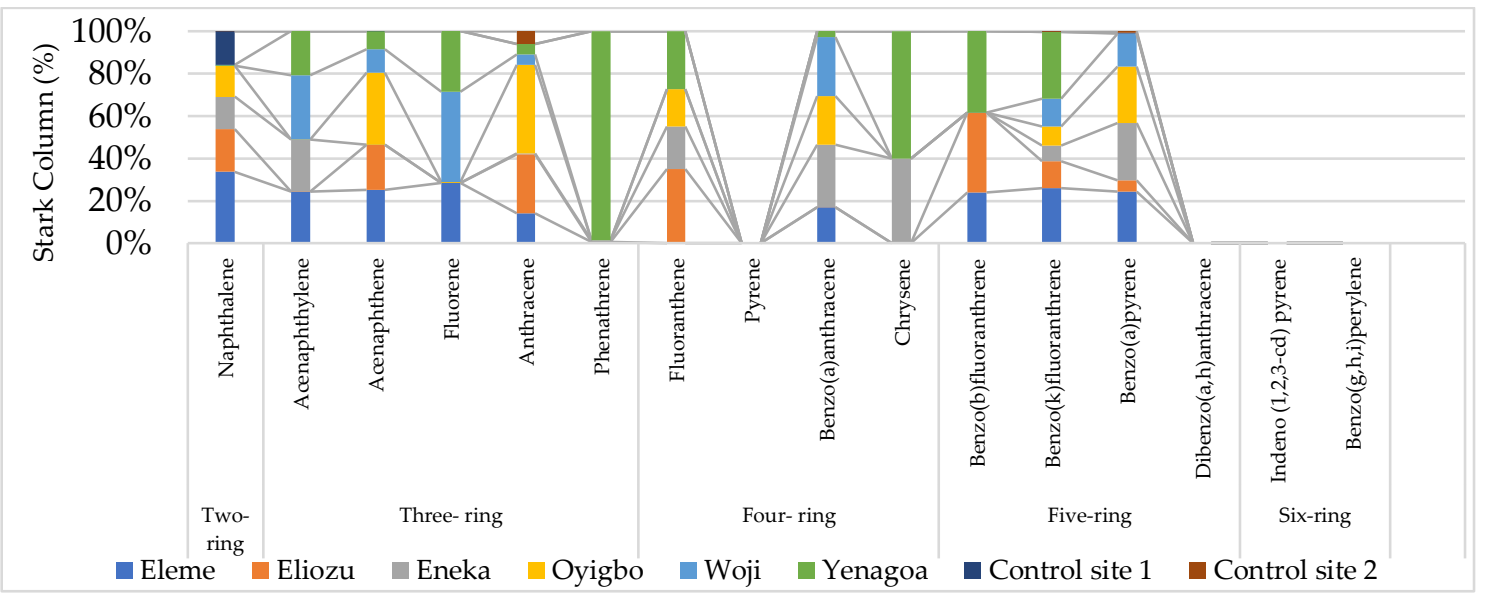

Figure 2. Percentage stark column of PAHs in soil dumpsite. 
Environmental Analysis Health and Toxicology 2021, 36(4):e2021023

\begin{tabular}{|c|c|c|c|c|c|c|c|c|}
\hline PAHs & Eleme & Eliozu & Eneka & Oyigbo & Woji & Yenagoa & $\begin{array}{l}\text { Control site } \\
1\end{array}$ & $\begin{array}{l}\text { Control site } \\
2\end{array}$ \\
\hline \multicolumn{9}{|l|}{ Two- ring } \\
\hline Naphthalene & $1.8751 \pm 0.0003$ & $1.1164 \pm 0.0001$ & $0.8683 \pm 0.0003$ & $0.8163 \pm 0.0003$ & $0.006 \pm 0.002$ & $0.011 \pm 0.0026$ & $0.8862 \pm 0.0002$ & $0.0003 \pm 0.0002$ \\
\hline \multicolumn{9}{|l|}{ Three- ring } \\
\hline Acenaphthylene & $0.7706 \pm 0.0002$ & $0.0009 \pm 0.0003$ & $0.7709 \pm 0.0001$ & $0.0008 \pm 0.0003$ & $0.9622 \pm 0.0003$ & $0.6605 \pm 0.0002$ & $0.001 \pm 0.001$ & ND \\
\hline Acenaphthene & $0.6537 \pm 0.0024$ & $0.5592 \pm 0.0002$ & $0.0013 \pm 0.0003$ & $0.8853 \pm 0.0001$ & $0.2854 \pm 0.0003$ & $0.2254 \pm 0.0002$ & $0.0001 \pm 0.0001$ & $0.0002 \pm 0.0001$ \\
\hline Fluorene & $0.388 \pm 0.0032$ & $0.001 \pm 0.001$ & $0.0009 \pm 0.0001$ & $0.0051 \pm 0.0002$ & $0.5891 \pm 0.0002$ & $0.3891 \pm 0.0001$ & $0.0002 \pm 0.0001$ & $0.0004 \pm 0.0001$ \\
\hline Anthracene & $0.2269 \pm 0.2947$ & $0.4564 \pm 0.0002$ & $0.0052 \pm 0.0003$ & $0.6765 \pm 0.0001$ & $0.0821 \pm 0.0002$ & $0.0751 \pm 0.0002$ & ND & $0.1002 \pm 0.0002$ \\
\hline Phenanthrene & $0.0004 \pm 0.0002$ & ND & $0.0007 \pm 0.0002$ & ND & ND & $0.0843 \pm 0.0001$ & ND & ND \\
\hline \multicolumn{9}{|l|}{ Four- ring } \\
\hline Fluoranthene & ND & $0.0014 \pm 0.0004$ & $0.0008 \pm 0.0001$ & $0.0007 \pm 0.0002$ & ND & $0.0011 \pm 0.0002$ & ND & ND \\
\hline Pyrene & ND & ND & ND & ND & ND & ND & ND & ND \\
\hline *Benzo(a)anthracene & $0.5641 \pm 0.0001$ & $0.0095 \pm 0.0004$ & $0.9865 \pm 0.0003$ & $0.7675 \pm 0.0002$ & $0.9395 \pm 0.0004$ & $0.0861 \pm 0.0003$ & $0.0004 \pm 0$ & $0.0002 \pm 0.0002$ \\
\hline${ }^{*}$ Chrysene & ND & ND & $0.0004 \pm 0.0004$ & ND & ND & $0.0006 \pm 0$ & ND & ND \\
\hline \multicolumn{9}{|l|}{ Five-ring } \\
\hline${ }^{*}$ Benzo(b)fluoranthene & $0.5386 \pm 0$ & $0.8555 \pm 0.0117$ & ND & $0.0009 \pm 0.0002$ & $0.0006 \pm 0.0002$ & $0.8643 \pm 0.0011$ & $0.0002 \pm 0.0001$ & $0.0004 \pm 0.0002$ \\
\hline${ }^{*}$ Benzo(k)fluoranthene & $0.0264 \pm 0$ & $0.0126 \pm 0.0001$ & $0.0076 \pm 0.0005$ & $0.009 \pm 0.0002$ & $0.0132 \pm 0.0002$ & $0.0319 \pm 0.0001$ & $0.0001 \pm 0$ & $0.0002 \pm 0.0001$ \\
\hline *Benzo(a)pyrene & $0.1224 \pm 0.0005$ & $0.0264 \pm 0.0001$ & $0.1356 \pm 0.0004$ & $0.1355 \pm 0$ & $0.0773 \pm 0.0004$ & ND & $0.0027 \pm 0.0003$ & $0.003 \pm 0.0002$ \\
\hline *Dibenzo(a,h)anthracene & ND & $\mathrm{ND}$ & ND & ND & ND & ND & ND & ND \\
\hline \multicolumn{9}{|l|}{ Six-ring } \\
\hline${ }^{*}$ Indeno $(1,2,3$-cd)pyrene & ND & ND & ND & ND & ND & ND & ND & ND \\
\hline Benzo(g,h,i)perylene & ND & ND & ND & ND & ND & ND & ND & ND \\
\hline$\Sigma$ LMW PAHs & 3.9147 & 2.1339 & 1.6473 & 2.384 & 1.9248 & 1.4454 & 0.8875 & 0.1011 \\
\hline$\Sigma$ HMW PAHs & 1.2515 & 0.9054 & 1.1309 & 0.9136 & 1.0306 & 0.984 & 0.0034 & 0.0038 \\
\hline$\Sigma 16$ PAHs & 5.1662 & 3.0393 & 2.7782 & 3.2976 & 2.9554 & 2.4294 & 0.8909 & 0.1049 \\
\hline$\Sigma$ Carcinogenic PAHs & 1.2515 & 0.904 & 1.1301 & 0.9129 & 1.0306 & 0.9829 & 0.0034 & 0.0038 \\
\hline
\end{tabular}




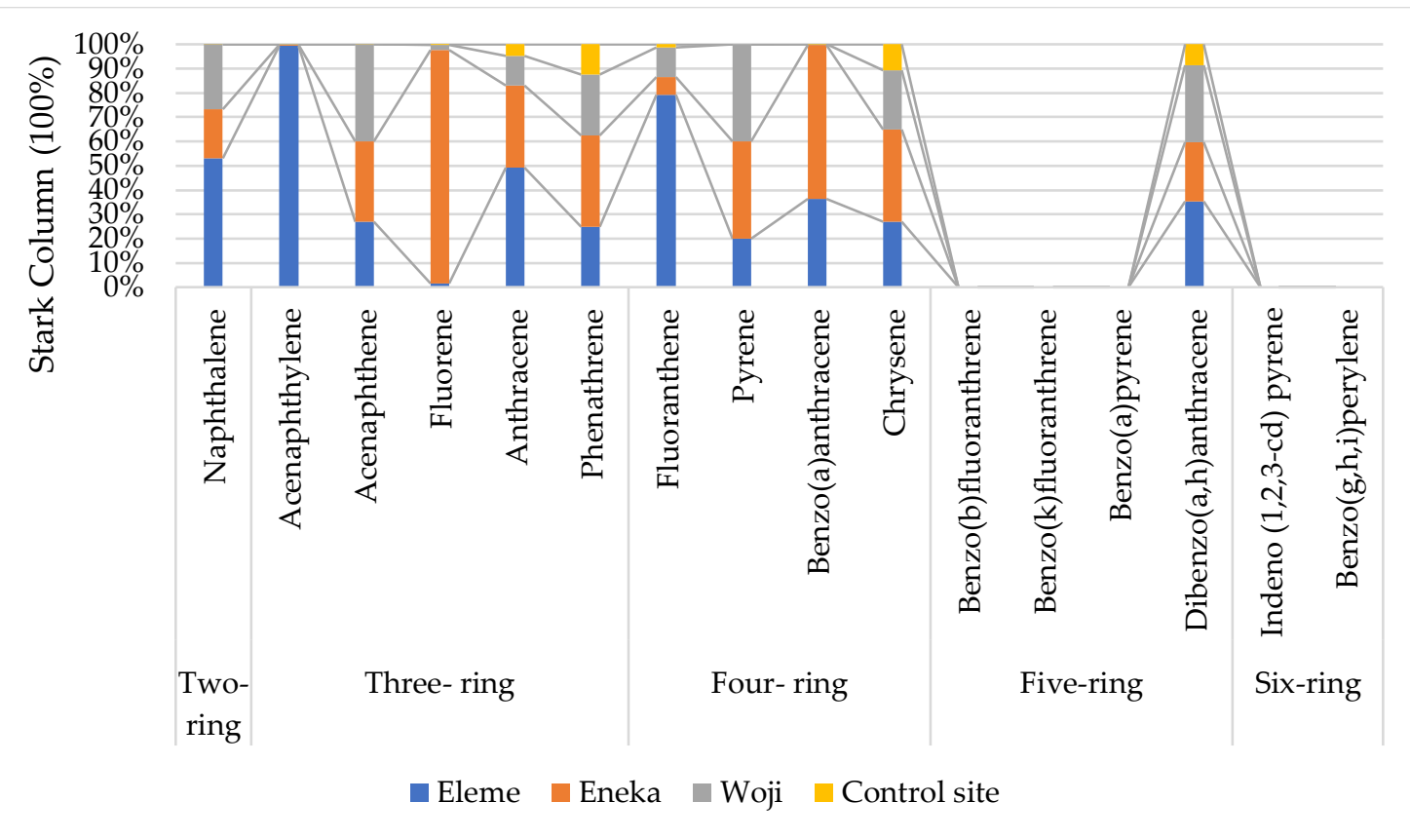

Figure 3. Percentage stark column of PAHs in borehole water.

Table 3. PAHs concentrations $(\mathrm{mg} / \mathrm{L})$ in borehole water.

\begin{tabular}{|c|c|c|c|c|}
\hline PAHs & Eleme & Eneka & Woji & Control site 1 \\
\hline \multicolumn{5}{|l|}{ Two- ring } \\
\hline Naphthalene & $1.7762 \pm 0.0003$ & $0.6791 \pm 0.0003$ & $0.8893 \pm 0.0004$ & $0.0021 \pm 0.0003$ \\
\hline \multicolumn{5}{|l|}{ Three- ring } \\
\hline Acenaphthylene & $0.233 \pm 0.0002$ & $0.001 \pm 0.0002$ & $<0.001 \pm 0.0002$ & $<0.001 \pm 0$ \\
\hline Acenaphthene & $0.1875 \pm 0.0003$ & $0.2287 \pm 0.0002$ & $0.2763 \pm 0.0003$ & $<0.001 \pm 0.0001$ \\
\hline Fluorene & $0.006 \pm 0.0002$ & $0.3891 \pm 0.0001$ & $0.0096 \pm 0.0005$ & $<0.001 \pm 0.0001$ \\
\hline Anthracene & $0.0032 \pm 0.0003$ & $0.0022 \pm 0.0003$ & $<0.001 \pm 0.0002$ & $<0.001 \pm 0$ \\
\hline Phenanthrene & $0.2008 \pm 0.0001$ & $0.3007 \pm 0.0001$ & $0.2004 \pm 0.0004$ & $0.1004 \pm 0.0002$ \\
\hline \multicolumn{5}{|l|}{ Four- ring } \\
\hline Fluoranthene & $0.0571 \pm 0.0005$ & $0.0052 \pm 0.0003$ & $0.0087 \pm 0.0003$ & $<0.001 \pm 0.0002$ \\
\hline Pyrene & $<0.001 \pm 0.0001$ & $<0.001 \pm 0.0002$ & $<0.001 \pm 0.0002$ & $<0.001 \pm 0$ \\
\hline *Benzo(a)anthracene & $0.5411 \pm 0.0054$ & $0.9395 \pm 0.0004$ & $0.0038 \pm 0.0002$ & $<0.001 \pm 0.0001$ \\
\hline${ }^{*}$ Chrysene & $<0.001 \pm 0$ & $0.0014 \pm 0.0002$ & $0.001 \pm 0.0001$ & $<0.001 \pm 0.0001$ \\
\hline \multicolumn{5}{|l|}{ Five-ring } \\
\hline${ }^{*} \operatorname{Benzo}(b)$ fluoranthene & ND & ND & ND & ND \\
\hline${ }^{*} \operatorname{Benzo}(\mathrm{k})$ fluoranthene & ND & ND & ND & ND \\
\hline *Benzo(a)pyrene & ND & ND & ND & ND \\
\hline *Dibenzo(a,h)anthracene & $0.0029 \pm 0.0002$ & $0.002 \pm 0.0003$ & $0.0026 \pm 0.0002$ & $0.0007 \pm 0.0002$ \\
\hline \multicolumn{5}{|l|}{ Six-ring } \\
\hline *Indeno (1,2,3-cd)pyrene & ND & ND & ND & ND \\
\hline Benzo(g,h,i)perylene & ND & ND & ND & ND \\
\hline$\Sigma$ LMW PAHs & 2.4067 & 1.6008 & 1.3771 & 0.1036 \\
\hline$\Sigma$ HMW PAHs & 0.6023 & 0.9485 & 0.0164 & 0.0024 \\
\hline$\Sigma 16$ PAHs & 3.009 & 2.5493 & 1.3935 & 0.1060 \\
\hline$\Sigma$ Carcinogenic PAHs & 0.545 & 0.9429 & 0.0073 & 0.0014 \\
\hline
\end{tabular}

Values are mean \pm standard deviation of triplicate determination. ND= Not Detected; detection limits for all the PAHs were $<0.001 \mathrm{mg} / \mathrm{L}>$. 


\section{Molecular diagnostic ratio of PAHs}

Molecular diagnostic ratio is a widely used method to ascertain the sources of PAHs present in different environmental matrix; as several studies such as Adedosu et al. [36], Ekpete et al. [37], Bucheli et al. [45], and Shamilishvily et al. [46] have been used to derive ratios of specific PAHs isomers to differentiate pyrogenic (combustion) and petrogenic (discharge of petroleum product e.g., oil spillage) PAHs sources. The individual compound ratios are identified to provide precise and consistent estimations of the sources of PAHs [35]. The results of the calculated diagnostic ratios are shown in (Table 4), where the determination of PAHs sources using the diagnostic ratios showed that the ratio of Anth/ (Anth + Phe) values in the soil and borehole water samples across the study areas were all greater than 0.1 which is indicative of pyrogenic source [45]. All the values Flua/Pyr+Flua were beyond detectable limits across the studied soil dumpsites whereas the values recorded for Flua/Pyr+Flua in all the borehole water sampling sites were greater than 0.5, which indicates that the PAHs are due to diesel emissions, grass, wood, and coal combustion [47]. This is possibly due to use of generating plants use by industries around the study areas. The ratio of $\mathrm{BaA} /(\mathrm{BaA}+\mathrm{Chr})$ less than $0.2,0.2-0.35$ and greater than 0.35 are indication of petrogenic, mixed and pyrogenic sources respectively [48]. The value of $\mathrm{BaA} /(\mathrm{BaA}+\mathrm{Chr})$ for all the sampling sites is greater than 0.35 indicating a pyrogenic source (combustion of coal, wood, and vehicular emissions). Petrogenic sources are characterize with the predominance of low molecular weight hydrocarbons containing (2-3 fused aromatic rings) PAHs over the high molecular weight (4-6 fused aromatic rings) PAHs. The ratio of low molecular weight PAHS to high molecular weight PAHs greater than 1 indicates a petrogenic source $[49,50]$, thus values recorded for the ratio of low molecular weight to high molecular weight (LMW/HMW) for all the sampling sites is more than 1 and is indicative of petrogenic sources. The ratio of (Phen/Ant) greater than 15 is an indication of petrogenic while (Phen/Anth) less than 10 is pyrogenic source [51]. All the values in the studied samples are less than 10 indicating a pyrogenic source. The use of the different source of diagnostic ratios of PAHs has shown that pyrogenic source (incomplete combustion of organic materials such as combustion of fossil fuel, wood, and coal) on most of the studied dumpsites predominates than petrogenic sources.

Table 4. Molecular diagnostic ratio of PAHs in the soil dumpsites and borehole water.

\begin{tabular}{|c|c|c|c|c|c|c|}
\hline Soil dumpsites & Phen/Ant & $\begin{array}{l}\text { Ant/Ant+ } \\
\text { Phen }\end{array}$ & $\begin{array}{c}\mathrm{B}(\mathrm{a}) \mathrm{A} / \mathrm{B}(\mathrm{a}) \mathrm{A}+ \\
\text { Chry }\end{array}$ & LMW/HMW & $\begin{array}{c}\text { Carc. PAHs / } \\
\text { Total PAHs }\end{array}$ & $\begin{array}{c}\text { Flua/ (Pry + } \\
\text { Flua) }\end{array}$ \\
\hline Eliozu & - & 1 & 1 & 2.094 & 0.297 & - \\
\hline Yenagoa & 1.122 & 0.471 & 0.993 & 1.468 & 0.404 & - \\
\hline Eneka & 0.135 & 0.881 & 0.999 & 1.674 & 0.407 & - \\
\hline Oyibo & - & 1 & 1 & 2.574 & 0.277 & - \\
\hline Woji & - & 1 & 1 & 1.862 & 0.348 & - \\
\hline Eleme & 0.0017 & 0.998 & 1 & 3.128 & 0.2422 & - \\
\hline Control site 1 & - & - & 1 & 261.37 & 0.0038 & - \\
\hline Control site 2 & - & 1 & 1 & 26.60 & 0.0362 & - \\
\hline \multicolumn{7}{|l|}{$\begin{array}{l}\text { Borehole water } \\
\text { sites }\end{array}$} \\
\hline Eneka & 0.0073 & $0 . .9927$ & 0.9985 & 1.6877 & 0.369 & 0.9285 \\
\hline Eleme & 0.016 & 0.9843 & 0.9981 & 3.9958 & 0.181 & 0.9965 \\
\hline Woji & 0.0039 & 0.9960 & 0.8085 & 83.96 & 0.005 & 0.9560 \\
\hline Control site 1 & 0.0029 & 0.9970 & 0.4285 & 43.16 & 0.013 & 1.0000 \\
\hline
\end{tabular}

Fluoranthene(Flua), Pyrene(pyr), Anthracene(Anth), Phenanthrene (Phen), Low molecular weight (LMW), High molecular weight (Hmw), Benzo(a)anthracene, B(a)A; Chrysene (Chry).

\section{Relationship of PAHs components across soil dumpsite and borehole water}

Multivariate analysis was conducted on soil dumpsite and borehole water to determine Pearson correlation (PC) and principal component analysis (PCA) respectively. Multivariate analysis is widely used to determine the relationship between complex data source thereby deriving crucial information [52], so therefore, the PAHs concentration detected during laboratory analysis in soil dumpsite and borehole water sources was utilized for this study with regards to different locations.

Table 5 shows the PCA conducted for soil dumpsite and borehole water, which produced five factor aggregates, with cumulative variance of $69.96 \%$ using rotated varimax. So therefore, Factor 1 produced variance of $19.45 \%$ with presence of Ace-S, BaA-S, BAP-S, Acy-BW, Ant-BW, Pyr-BW, Chry-BW and DBA-BW. Factor 2 gave variance of $12.80 \%$ with PCA component as Acy-S and Phen-S. Factor 3 showed variance of 13.12\% with presence of Ant-S, Chry-S, BbF-S and BkF-S. Factor 4, Flu-S was present only at $11.27 \%$ variance, while Factor 5 produced variance of Nap-S, Nap-BW, Ace-BW, Phen-BW, Flua-BW accordingly. As for factor analysis conducted, there was presence of positive and negative aggregation, as it depicts that Factor 3 having positive aggregate, while other factor $(1,2,4,5)$ had negative aggregate. BaA$\mathrm{S}$ and $\mathrm{BaA}-\mathrm{BW}$ were in Factor 1 that means that BaA leachate transfer took place from soil (-0.92) to borehole water (-0.67), 
Okechukwu et al. I Pollution investigation \& risk assessment of PAHs in soil and water

while Flu-S increased from soil (-0.43) to borehole water (-0.66). Factor 5 produced Nap-S leachate transfer decreased from soil (-0.81) and borehole water (-0.74).

Table 5. Principal component analysis of PAHs across soil and borehole water.

\begin{tabular}{|c|c|c|c|c|c|}
\hline & Factor 1 & Factor 2 & Factor 3 & Factor 4 & Factor 5 \\
\hline Nap-S & & & & & -0.81 \\
\hline Ace-S & -0.82 & & 0.41 & & \\
\hline Acy-S & & -0.94 & & & \\
\hline Flu-S & -0.43 & & & 0.80 & \\
\hline Phen-S & & -0.96 & & & \\
\hline Ant-S & & & 0.88 & & \\
\hline Flua-S & & & 0.65 & -0.45 & \\
\hline${ }^{*} \mathrm{BaA}-\mathrm{S}$ & -0.92 & & & & \\
\hline${ }^{*}$ Chry-S & & & 0.83 & & \\
\hline${ }^{*} \mathrm{BbF}-\mathrm{S}$ & & & 0.78 & & \\
\hline${ }^{*} \mathrm{BkF}-\mathrm{S}$ & & & 0.84 & & \\
\hline${ }^{*} \mathrm{BaP}-\mathrm{S}$ & -0.72 & -0.55 & & & \\
\hline Nap-BW & -0.63 & & & & -0.74 \\
\hline Ace-BW & & & & & -0.96 \\
\hline Acy-BW & -0.94 & & & & \\
\hline Flu-BW & -0.66 & & & -0.71 & \\
\hline Phen-BW & -0.64 & & & & -0.75 \\
\hline Ant-BW & -0.87 & & & & \\
\hline Flua-BW & & & & & -0.93 \\
\hline Pyr-BW & -0.97 & & & & \\
\hline${ }^{*} \mathrm{BaA}-\mathrm{BW}$ & -0.67 & & & -0.59 & -0.40 \\
\hline${ }^{*}$ Chry-BW & -0.87 & & & & \\
\hline${ }^{*}$ DBA-BW & -0.80 & & & & -0.51 \\
\hline Eigenvalue & 8.325 & 2.965 & 3.631 & 2.484 & 4.881 \\
\hline Variance (\%) & 19.452 & 12.803 & 13.12 & 11.266 & 13.314 \\
\hline Cumulative (\%) & 19.452 & 32.255 & 45.375 & 56.64 & 69.955 \\
\hline
\end{tabular}

S-Soil dumpsite; BW-Borehole water; Nap-Naphthalene; Ace-Acenaphthene; Acy-Acenaphthylene; Flu-Fluorene; Phen-Phenanthrene; Ant-Anthracene; Flua -Fluoranthene; BaA-Benzo(a)anthracene; Chry-Chrysene; BbF-Benzo(b)fluoranthene; BkF-Benzo(k)fluoranthene; BaP-Benzo(a)pyrene; DBA-

Dibenz(ah)anthracene.

Table 6 gives the correlative potential of PAHs in soil dumpsite and borehole water across all sampling locations, as seen, the PC showed presence of strong ( $\geq 0.70 \mathrm{PC} \leq 1.00)$, medium $(\geq 0.30 \mathrm{PC} \leq 0.69)$ and weak $(\geq 0.00 \mathrm{PC} \leq 0.29)$ correlations [52]. Vertical Ace-S produced strong correlation with Flu-S, Nap-BW, Acy-BW, Ant-BW, Pyr-BW, Chry-BW and DBA-BW, also Acy-S correlated strongly with Phen-S (0.89), while BaA-S correlated with Bap-S, Acy-BW, Ant-BW, Pyr-BW, Chry-BW. There was strong correlation as one moves towards borehole water in PAHs components. The correlation (Table 5) conducted produced positive regression that implies PAHs component were from similar pollution source and migratory behavior across soil and borehole water system via leaching route, while negative correlation implies dissimilar or different polluting source [1]. 
Environmental Analysis Health and Toxicology 2021, 36(4):e2021023

Table 6. Correlation matrices of PAHs in soil and borehole water.

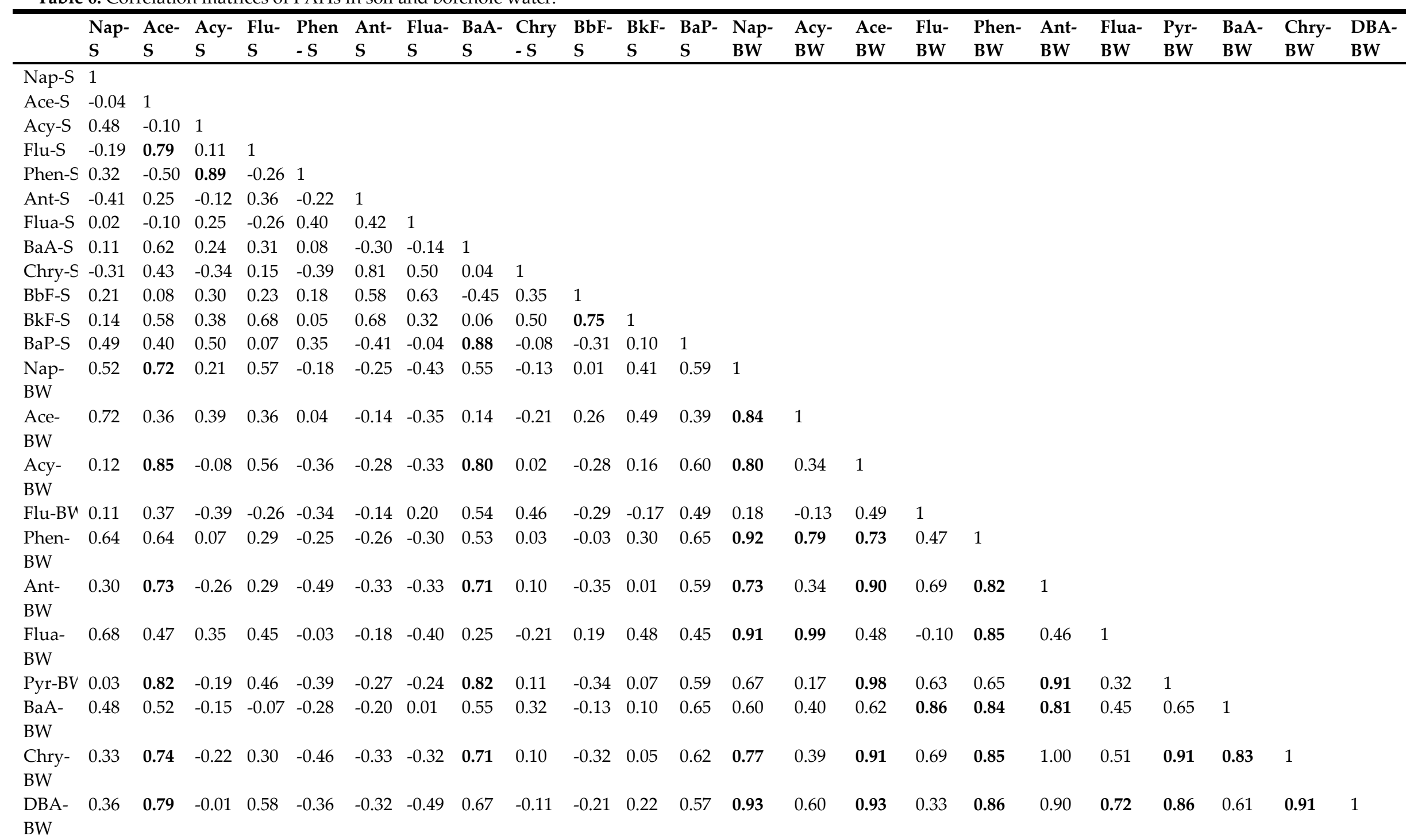

${ }^{1} \mathrm{~S}$ - Soil dumpsite; BW - Borehole water; Nap - Naphthalene; Ace - Acenaphthene; Acy - Acenaphthylene; Flu - Fluorene; Phen - Phenanthrene; Ant - Anthracene; Flua - Fluoranthene; BaA - Benzo(a)anthracene; ChryChrysene; BbF- Benzo(b)fluoranthene; BkF - Benzo(k)fluoranthene; BaP - Benzo(a)pyrene; DBA - Dibenz(ah)anthracene

${ }^{2}$ Correlation matrices, $\mathrm{p}$-value $\leq 0.0$ 


\section{Relationship of cumulative PAHs component across locations.}

Table 7 gives the PCA analysis conducted for cumulative PAHs component across different locations in tandem to soil dumpsite and borehole water, which produced four factors at $65.85 \%$ cumulative variance. Factor 1 gave the high number of aggregates (Eleme-S, Eliozu-S, control site 1, Eleme-BW and Woji-BW) as compared to other factors that is factor 2 (Eneka-S, Woji-S), factor 3 (control site 2) and factor 4 (Yenagoa-S). We can also derive that there was slight increase from Eleme-S (-0.87) to Eleme (-0.96) in relation to Eneka-S (-0.43) and Eneka-BW (-0.56).

Table 7. Principal component analysis of PAHs across locations

\begin{tabular}{|c|c|c|c|c|}
\hline & Factor 1 & Factor 2 & Factor 3 & Factor 4 \\
\hline Eleme-S & -0.87 & & & \\
\hline Eliozu-S & -0.78 & & & -0.41 \\
\hline Eneka-S & -0.43 & -0.85 & & \\
\hline Oyigbo-S & -0.49 & & 0.67 & \\
\hline Woji-S & & -0.91 & & \\
\hline Yenagoa-S & & & & -0.94 \\
\hline Control site 1-S & -0.96 & & & \\
\hline Control site 2-S & & & 0.82 & \\
\hline Eleme-BW & -0.96 & & & \\
\hline Eneka-BW & -0.56 & & & \\
\hline Woji-BW & -0.96 & & & \\
\hline Control site 1-BW & & & -0.41 & \\
\hline Eigenvalue & 4.948 & 2.04 & 1.64 & 1.49 \\
\hline Variance (\%) & 22.26 & 16.08 & 14.13 & 13.38 \\
\hline Cumulative (\%) & 22.26 & 38.34 & 52.47 & 65.85 \\
\hline
\end{tabular}

Table 8 shows the correlation matrices conducted for cumulative PAHs component across different study locations, as such there was presence of weak, medium, and strong correlation. Vertical Eleme-S showed strong correlation with Eliozu-S (0.74), control site 1-S (0.85), Eleme-BW (0.79) and Woji-BW (0.82). Eliozu-S and Woji-BW produced correlation (0.70), control site 1-S correlated strongly with Eleme-BW (0.95) and Woji-BW (0.93). Eleme-BW and Woji-BW correlated at 0.91 Therefore, the vertical correlation (Eneka-S, Woji-S, Yenagoa-S) and horizontal correlation (Eneka-S, Oyigbo-S, Woji-S, Yenagoa-S, control site 2, Eneka-BW, control site 1-BW) implies that soil dumpsite and borehole water interact weak and medium pollution source.

Table 8. Correlation of PAHs in soil and borehole water.

\begin{tabular}{|c|c|c|c|c|c|c|c|c|c|c|c|c|}
\hline & $\begin{array}{l}\text { Eleme } \\
-S\end{array}$ & $\begin{array}{l}\text { Eliozu } \\
-S\end{array}$ & $\begin{array}{l}\text { Eneka } \\
-S\end{array}$ & $\begin{array}{l}\text { Oyigbo } \\
-S\end{array}$ & $\begin{array}{l}\text { Woji - } \\
\text { S }\end{array}$ & $\begin{array}{l}\text { Yenago } \\
\text { a -S }\end{array}$ & $\begin{array}{l}\text { Control } \\
\text { site 1-S }\end{array}$ & $\begin{array}{l}\text { Control } \\
\text { site 2-S }\end{array}$ & $\begin{array}{l}\text { Eleme - } \\
\text { BW }\end{array}$ & $\begin{array}{l}\text { Eneka - } \\
\text { BW }\end{array}$ & $\begin{array}{l}\text { Woji } \\
\text { BW }\end{array}$ & $\begin{array}{l}\text { - Control site } \\
\text { 1-BW }\end{array}$ \\
\hline Eleme-S & 1 & & & & & & & & & & & \\
\hline Eliozu-S & 0.74 & 1 & & & & & & & & & & \\
\hline Eneka-S & 0.69 & 0.16 & 1 & & & & & & & & & \\
\hline Oyigbo-S & 0.58 & 0.53 & 0.44 & 1 & & & & & & & & \\
\hline Woji-S & 0.21 & -0.33 & 0.62 & 0.15 & 1 & & & & & & & \\
\hline Yenagoa-S & 0.19 & 0.24 & 0.03 & -0.30 & 0.35 & 1 & & & & & & \\
\hline $\begin{array}{l}\text { Control sit } \\
1-S\end{array}$ & 0.85 & 0.68 & 0.51 & 0.45 & -0.20 & -0.21 & 1 & & & & & \\
\hline $\begin{array}{l}\text { Control sit } \\
2-S\end{array}$ & -0.10 & 0.16 & -0.18 & 0.33 & -0.14 & -0.14 & -0.1 & 1 & & & & \\
\hline Eleme-BW & 0.79 & 0.60 & 0.47 & 0.37 & -0.22 & -0.23 & 0.95 & -0.16 & 1 & & & \\
\hline Eneka-BW & 0.26 & 0.18 & 0.00 & 0.05 & -0.25 & -0.28 & 0.46 & -0.22 & 0.67 & 1 & & \\
\hline Woji-BW & 0.82 & 0.70 & 0.40 & 0.54 & -0.24 & -0.23 & 0.93 & -0.14 & 0.91 & 0.49 & 1 & \\
\hline $\begin{array}{l}\text { Control sit } \\
\text { 1-BW }\end{array}$ & -0.20 & -0.19 & -0.18 & -0.20 & -0.22 & -0.13 & -0.1 & -0.10 & -0.01 & 0.10 & 0.12 & 1 \\
\hline
\end{tabular}




\section{Health and exposure risk assessment}

The degree of PAHs exposure to humans is due to the influence of chronic daily intake (CDI) across different exposure matrices (ingestion, dermal and inhalation) of soil dumpsite and borehole water that are interconnected via chemical infiltrations and its corresponding biochemical transformations with flora and faunas [2,53]. Health and exposure risk assessment was conducted on PAHs concentration for soil dumpsite and borehole water using USEPA risk models that gives the exposure ratio with regards to health implication (carcinogenic and non-carcinogenic) for adults and children respectively. As seen in Appendix 1 and 2, cancer risk for adults and children were evaluated in soil dumpsite which produced cumulative exposure matrices in Table 9, which implies that adults and children are at serious risk of having cancer related issues over a period of time in tandem with USEPA cancer reference of $0.000001-0.0001$ (1.0E-06 - 1.0E-04) [54-56] For Appendix 3 and 4, hazard index gave cumulative hazard quotient (non-cancer risk) that were within USEPA hazard range $(0-1)[54,56]$.

Appendix 4 and 5 shows that cumulative cancer risk of borehole water that were within USEPA cancer reference thus implies there will be no cancer related issues, while for appendix 6 and 7 shows that the sum-total of hazard quotient for ingestion and dermal contact were within USEPA hazard range except for inhalation that was above 1 correspondingly.

The utilization of individual PAHs components with their corresponding cancer slope factor and reference dose has immerse influence of incremental lifetime cancer and non-cancer risk [31], as children is more at risk compared to adults, thereby as PAHs is absorbed into the human body, they act more in cellular functioning negatively leading to tissues degradation, poor organ development and improper functioning of the central nervous system [53]. The effects of carcinogenic PAHs have been reported to be more prominent in certain parts of the body which include the liver, lung gastro-intestine, bladder, and skin (ATSDR, 2013). Even though there is concern over the potential health risk of the populace, most especially the children living close to dumpsite areas due to the possibility of dispersal of PAHs to the entire environment and as well inherent hand to mouth activities leading to long life exposure and residents and resident's detrimental health. As we can see across the entire summarized values of cumulative cancer risk and hazard quotient, there were diverse values that implies that adults and children are at risk over a period of time based on age, exposure period, exposure frequency, as such using USEPA reference age of 70 years for cancer risk evaluation, it shows that inhalation can be detrimental since it contributed more as compared to ingestion (oral) and dermal (skin contact), as such one should expect that inhalation of PAHs into the lungs get absorbed into the blood stream leading to blood cancer and respiratory based cancer [55,57]. For ingestion and dermal exposure can lead to carcinogenesis leading to formation of cellular tumors, DNA degeneration and abnormal genetic changes over a period [58,59]. Although other information has shown that PAHs is removed from the body by urination as hydroxylated PAHs metabolites [57,60].

The total cancer risk and hazard index were summed up in terms of all exposure (Table 10), which shows that Eleme had the highest cancer risk thus implying that adults and children leaving within 500-1000 $\mathrm{m}$ in tandem to other activities that is taken place in the vicinity such as oil and gas and chemical industries will experience immerse cancer issues such as cancer of the skin, lungs, bladder, liver, stomach as well as well as reduction in reproductive, immunity, neurologic and bodily development [61-63]. Although one cannot conclude that Eleme contributed to the cumulative PAHs concentration without due diligent to other petroleum exploratory activities (gas flaring, flue-gas venting, effluent release into water body) taken place across offshore and land shore areas in oil-producing area, southern Nigeria [4,15,64]. Therefore, petroleum and chemical industries is assumed to contribute immensely to the total PAHs release in tandem to automobile and heavy duty, residential and natural releases accordingly. 
Table 9. Total cancer risk and non-cancer risk of heavy metals across soil and borehole water sources

\begin{tabular}{|c|c|c|c|c|c|c|c|c|c|}
\hline \multirow{3}{*}{$\begin{array}{l}\text { Sample } \\
\text { Location }\end{array}$} & \multirow{3}{*}{$\begin{array}{l}\text { Exposure } \\
\text { Medium }\end{array}$} & \multicolumn{4}{|c|}{ Soil dumpsites } & \multicolumn{4}{|c|}{ Borehole water samples } \\
\hline & & \multicolumn{2}{|c|}{ Total cancer risk } & \multicolumn{2}{|c|}{ Hazard index } & \multicolumn{2}{|c|}{ Total cancer risk } & \multicolumn{2}{|c|}{ Hazard index } \\
\hline & & Adults & Children & Adults & Children & Adults & Children & Adults & Children \\
\hline \multirow[t]{3}{*}{ Eleme } & Ingestion & $7.83 \mathrm{E}-01$ & $1.93 \mathrm{E}+00$ & 2.17E-02 & $1.78 \mathrm{E}-01$ & $8.12 \mathrm{E}-13$ & $3.00 \mathrm{E}-09$ & $1.90 \mathrm{E}-05$ & $3.16 \mathrm{E}-05$ \\
\hline & Dermal & 4.13E-03 & 3.05E-02 & $1.29 \mathrm{E}-06$ & 8.89E-05 & $1.28 \mathrm{E}-12$ & 4.90E-09 & 3.77E-05 & $1.63 \mathrm{E}-05$ \\
\hline & Inhalation & $5.27 \mathrm{E}+03$ & $8.11 \mathrm{E}+02$ & 5.40E-02 & $1.11 \mathrm{E}-01$ & $1.96 \mathrm{E}-05$ & 4.60E-01 & $1.09 \mathrm{E}+04$ & $2.18 \mathrm{E}+04$ \\
\hline \multirow[t]{3}{*}{ Eliozu } & Ingestion & 3.69E-01 & $9.08 \mathrm{E}-01$ & 1.10E-03 & $9.01 \mathrm{E}-03$ & $1.89 \mathrm{E}-10$ & $1.88 \mathrm{E}-09$ & $3.20 \mathrm{E}-05$ & 5.33E-05 \\
\hline & Dermal & $1.95 \mathrm{E}-03$ & $1.44 \mathrm{E}-02$ & $6.38 \mathrm{E}-07$ & $4.41 \mathrm{E}-05$ & 2.98E-10 & 3.06E-09 & $5.84 \mathrm{E}-05$ & $2.52 \mathrm{E}-05$ \\
\hline & Inhalation & $2.61 \mathrm{E}+03$ & $4.01 \mathrm{E}+02$ & $3.21 \mathrm{E}-02$ & 6.59E-02 & $4.56 \mathrm{E}-03$ & 4.52E-01 & $2.84 \mathrm{E}+04$ & $5.69 \mathrm{E}+04$ \\
\hline \multirow[t]{3}{*}{ Eneka } & Ingestion & 7.86E-01 & $1.94 \mathrm{E}+00$ & 2.09E-02 & $1.72 \mathrm{E}-01$ & NA & NA & NA & NA \\
\hline & Dermal & 4.15E-03 & $3.06 \mathrm{E}-02$ & 7.88E-07 & $5.45 \mathrm{E}-05$ & NA & NA & NA & NA \\
\hline & Inhalation & $4.74 \mathrm{E}+03$ & $7.29 \mathrm{E}+02$ & $2.51 \mathrm{E}-02$ & $5.14 \mathrm{E}-02$ & NA & NA & NA & NA \\
\hline \multirow[t]{3}{*}{ Oyigbo } & Ingestion & 6.93E-01 & $1.71 \mathrm{E}+00$ & $1.08 \mathrm{E}-03$ & $8.86 \mathrm{E}-03$ & NA & NA & NA & NA \\
\hline & Dermal & $3.66 \mathrm{E}-03$ & $2.70 \mathrm{E}-02$ & $5.82 \mathrm{E}-07$ & 4.02E-05 & NA & NA & NA & NA \\
\hline & Inhalation & $4.20 \mathrm{E}+03$ & $6.47 \mathrm{E}+02$ & $2.36 \mathrm{E}-02$ & 4.83E-02 & NA & NA & NA & NA \\
\hline \multirow[t]{3}{*}{ Woji } & Ingestion & 5.89E-01 & $1.45 \mathrm{E}+00$ & $2.58 \mathrm{E}-02$ & 2.12E-01 & $5.69 \mathrm{E}-13$ & $1.06 \mathrm{E}-10$ & 8.50E-06 & $1.41 \mathrm{E}-05$ \\
\hline & Dermal & 3.11E-03 & 2.29E-02 & $6.75 \mathrm{E}-07$ & 4.67E-05 & 8.94E-13 & $1.73 \mathrm{E}-10$ & 2.38E-05 & $1.03 \mathrm{E}-05$ \\
\hline & Inhalation & $3.20 \mathrm{E}+03$ & $4.92 \mathrm{E}+02$ & 3.94E-04 & 8.09E-04 & 1.37E-05 & $1.22 \mathrm{E}-01$ & $2.13 \mathrm{E}+04$ & $2.85 \mathrm{E}+04$ \\
\hline \multirow[t]{3}{*}{ Yenagoa } & Ingestion & 3.31E-01 & $8.15 \mathrm{E}-01$ & 1.79E-02 & $1.47 \mathrm{E}-01$ & NA & NA & NA & NA \\
\hline & Dermal & 1.75E-03 & $1.29 \mathrm{E}-02$ & 5.27E-07 & 3.65E-05 & NA & NA & NA & NA \\
\hline & Inhalation & $1.81 \mathrm{E}+03$ & $2.78 \mathrm{E}+02$ & 4.98E-04 & $1.02 \mathrm{E}-03$ & NA & NA & NA & NA \\
\hline Control & Ingestion & $9.00 \mathrm{E}-03$ & 2.22E-02 & 3.73E-04 & $3.06 \mathrm{E}-03$ & 8.12E-14 & $2.31 \mathrm{E}-11$ & $1.49 \mathrm{E}-07$ & $2.49 \mathrm{E}-07$ \\
\hline \multirow[t]{2}{*}{ Site 1} & Dermal & 4.75E-05 & $3.51 \mathrm{E}-04$ & 2.93E-07 & 2.02E-05 & $1.28 \mathrm{E}-13$ & 3.78E-11 & $2.51 \mathrm{E}-07$ & $1.08 \mathrm{E}-07$ \\
\hline & Inhalation & $5.31 \mathrm{E}+02$ & 8.17E+01 & 2.54E-02 & $5.21 \mathrm{E}-02$ & $1.96 \mathrm{E}-06$ & $3.41 \mathrm{E}-03$ & $3.37 \mathrm{E}+01$ & $6.74 \mathrm{E}+01$ \\
\hline Control & Ingestion & 9.95E-03 & $2.45 \mathrm{E}-02$ & 7.50E-06 & $6.16 \mathrm{E}-05$ & NA & NA & NA & NA \\
\hline \multirow[t]{2}{*}{ Site 2} & Dermal & $5.25 \mathrm{E}-05$ & 3.87E-04 & 3.22E-09 & 2.23E-07 & NA & NA & NA & NA \\
\hline & Inhalation & $5.41 \mathrm{E}+01$ & $8.32 \mathrm{E}+00$ & 8.98E-06 & $1.84 \mathrm{E}-05$ & NA & NA & NA & NA \\
\hline
\end{tabular}

Table 10. Cancer risk and Hazard index of soil dumpsite and borehole water.

\begin{tabular}{lcccccccc}
\hline & \multicolumn{4}{c}{ Soil dumpsite } & \multicolumn{3}{c}{ Borehole water } \\
Sample & \multicolumn{2}{c}{ Total Cancer risk } & \multicolumn{2}{c}{ Hazard Index } & \multicolumn{2}{c}{ Total Cancer risk } & \multicolumn{2}{c}{ Hazard Index } \\
Location & Adults & Children & Adults & Children & Adults & Children & Adults & Children \\
\hline Eleme & $5.27 \mathrm{E}+03$ & $8.13 \mathrm{E}+02$ & $7.57 \mathrm{E}-02$ & $2.89 \mathrm{E}-01$ & $1.96 \mathrm{E}-05$ & $4.60 \mathrm{E}-01$ & $1.09 \mathrm{E}+04$ & $2.18 \mathrm{E}+04$ \\
Eliozu & $2.61 \mathrm{E}+03$ & $4.02 \mathrm{E}+02$ & $3.32 \mathrm{E}-02$ & $7.50 \mathrm{E}-02$ & $4.56 \mathrm{E}-03$ & $4.52 \mathrm{E}-01$ & $2.84 \mathrm{E}+04$ & $5.69 \mathrm{E}+04$ \\
Eneka & $4.74 \mathrm{E}+03$ & $7.31 \mathrm{E}+02$ & $4.60 \mathrm{E}-02$ & $2.23 \mathrm{E}-01$ & NA & NA & NA & NA \\
Oyigbo & $4.20 \mathrm{E}+03$ & $6.49 \mathrm{E}+02$ & $2.47 \mathrm{E}-02$ & $5.72 \mathrm{E}-02$ & NA & NA & NA & NA \\
Woji & $3.20 \mathrm{E}+03$ & $4.93 \mathrm{E}+02$ & $2.62 \mathrm{E}-02$ & $2.13 \mathrm{E}-01$ & $1.37 \mathrm{E}-05$ & $1.22 \mathrm{E}-01$ & $2.13 \mathrm{E}+04$ & $2.85 \mathrm{E}+04$ \\
Yenagoa & $1.81 \mathrm{E}+03$ & $2.79 \mathrm{E}+02$ & $1.84 \mathrm{E}-02$ & $1.48 \mathrm{E}-01$ & NA & NA & NA & NA \\
Control Site 1 & $5.31 \mathrm{E}+02$ & $8.17 \mathrm{E}+01$ & $2.58 \mathrm{E}-02$ & $5.52 \mathrm{E}-02$ & $1.96 \mathrm{E}-06$ & $3.41 \mathrm{E}-03$ & $3.37 \mathrm{E}+01$ & $6.74 \mathrm{E}+01$ \\
Control Site 2 & $5.41 \mathrm{E}+01$ & $8.34 \mathrm{E}+00$ & $1.65 \mathrm{E}-05$ & $8.02 \mathrm{E}-05$ & NA & NA & NA & NA \\
\hline NA: No data & & & & & & & &
\end{tabular}




\section{Conclusions}

The study investigated the concentration, sources (molecular diagnostics), health and exposure risk assessment of Polycyclic Aromatic Hydrocarbons (PAHs) from soil and borehole water samples in selected active dumpsites in Rivers and Bayelsa State, Nigeria. PAHs across the studied dumpsites showed significant contamination as Eleme contributed more as compared to other locations. Molecular diagnostics showed that low molecular weight PAHs dominated in comparison to high molecular weight PAHs in both soil and water samples as PAHs were from petrogenic and pyrogenic source, but the pyrogenic activities were predominant. Multivariate analyses were conducted for PAHs and locations gave principal component analysis (PCA) and Pearson correlation that were negative implying that they were from dissimilar polluting source and vice versa for positive across migration route. The results of health and exposure risk indicated that, in both adults and children, the inhalation pathway was the greatest contributor for cancer risk and non-cancer risk implying inhalation-based health issues over a period, as dermal pathway was the least contributor. Also, children were more at risk as compared to adults, as based on the result of this present study, it can be concluded that soils surrounding the dumpsites area are polluted by PAHs contaminants especially with known carcinogens (BaA, BbF, Bkf and $\mathrm{BaP})$ that in turn leach into water aquifer system leading to increase PAHs concentration, which poses adverse health threat to man and environment in maintain equitable balance. Therefore, public enlightenment should be created on environmental pollution, treatment and containment measures need to be put in place to avoid possible human exposure.

\section{Acknowledgement}

The authors wish to thank the laboratory officers of Jacio Environmental Limited Effurn, Delta State, Nigeria for their support and providing necessary facilities in carrying out this study.

\section{Conflict of interest}

We declare no conflict of interest as regards this article as the study was self-funded.

\section{CRediT author statement}

VIO: Conceptualization, Research design, Supervision; VUO: Methodology, Software, Data curation, Writing- Original draft preparation; DOO: Writing- Original draft preparation, Writing- Reviewing and Editing; ENN: Visualization, Investigation; PLO: Visualization and Investigation

\section{ORCID}

Victor Uchenna Okechukwu: 0000-0003-2012-1646

Daniel Omeodisemi Omokpariola: 0000-0003-1360-4340

Eucheria Nkiru Nweke: 0000-0003-4286-175X

Patrick Leonard Omokpariola: 0000-0002-4983-2719

\section{Supplementary Material}

The evaluation of data from health and exposure risk assessment are available as appendix $1-8$. This material is available online at www.eaht.org.

\section{References}

[1] Onwukeme VI, Okechukwu VU. Leaching matrix of selected heavy metals from soil to ground water sources in active dumpsites: A case study of Southern Nigeria. IOSR J Environ Sci, Toxicol Food Technol 2021;15(4): 1-18

[2] Omokpariola DO, Omokpariola PL. Health and exposure risk assessment of heavy metals in rainwater samples from selected locations in Rivers State, Nigeria. Phy Sci Rev. 2021. https://doi.org/10.1515/psr-2020-0090

[3] Sawyerr HO, Adeolu AT, Afolabi AS, Salami OO, Badmos BK. Impact of dumpsites on the quality of soil and groundwater in satellite towns of the Federal Capital Territory, Abuja, Nigeria. J Health Poll 2017;7(14):15-22. https://doi.org/10.5696/2156-9614-7.14.15

[4] Kabyl A, Yang M, Abbassi R, Li S. A risk-based approach to producing water management in offshore oil and gas operations. Proc Saf Environ Prot 2020;139:341-361. https://doi.org/10.1016/j.psep.2020.04.021

[5] Somani M, Amini N, Sadeghian B, Wang D, Fang L. Heavy metals and their source identification in particulate matter (PM2.5) in Isfahan City, Iran. J Environ Sci 2018;72:166-175. https://doi.org/10.1016/j.jes.2018.01.002 
[6] Omokpariola DO, Nduka JK, Omokpariola PL, Omokpariola ECO. Ionic composition of rainwater from different sampling surfaces across selected locations in Rivers State, Nigeria. World Sci News 2020;150:132-147.

[7] Ojaniyi, OF, Okoye PAC, Omokpariola DO. Heavy Metals Analysis and Health Risk Assessment of Three Fish Species, Surface Water and Sediment Samples in Ogbaru Axis of River Niger, Anambra State, Nigeria. Asian J Appl Chem Res 2021; 9(1): 64-81. https://doi.org/10.9734/AJACR/2021/v9i130205

[8] Mor S, Ravindra K, Dahiya RP, Chandra A. Leachate characterization and assessment of groundwater pollution near municipal solid waste dumpsite site. Environ Mon Ass 2006;118(1):435-456.https://doi.org/10.1007/s10661-006-1505-7

[9] Woodward J.P. Landfill guidelines report. In: Limited, (ed.) W.C.N. Hazard of burning at landfill. New Zealand: Ministry of Environment; 1997.

[10] World Health Organization (WHO) Guidelines for drinking-water quality: 4th ed. incorporating the first addendum. https://apps.who.int/iris/rest/bitstreams/1080656/retrieve.

[11] Maliszewska-Kordybach B. Sources, concentrations, fate and effects of polycyclic aromatic hydrocarbons (PAHs) in the environment. Part A: PAHs in Air. J Environ Studies 1999;8:131-136.

[12] World Health Organization (WHO). Health risks of persistent organic pollutants from long-range transboundary air Pollution. World Health Organization Regional Office for Europe, Copenhagen;2003,252- 259.

Assessed in 2003. https://apps.who.int/iris/handle/10665/107471

[13] Trapido M. Polycyclic aromatic hydrocarbons in Estonian soil: contamination and profiles. Environ. Poll 1999;105(1):6774. https://doi.org/10.1016/S0269-7491(98)00207-3

[14] Schloter M, Dilly O, Munch JC. Indicators for evaluating soil quality. Agr Ecosyst Environ 2003;98(1-3):255-262. https://doi.org/10.1016/S0167-8809(03)00085-9

[15] Omokpariola JO, Omokpariola DO, Chioma E, Omokpariola O. Risk assessment of polycyclic aromatic hydrocarbons and total petroleum hydrocarbons in oilfield produced water and sea water at Gulf of Guinea Oilfield, Nigeria. Advanced Journal of Chemistry. - Section B. 2011;3(1):68-85. https://doi.org/10.22034/ajcb.2021.121909

[16] Yang H, Wu X, Zhou LX, Yang ZM. Effect of dissolved organic matter on chlorotoluron sorption and desorption in soils. Pedosphere 2005;15(4):432-439.

[17] American Conference of Governmental Industrial Hygienists (ACGIH). Polycyclic aromatic hydrocarbons (PAHs) biologic exposure indices (BEI) Cincinnati, OH: American Conference of Governmental Industrial Hygienists 2005.

[18] Masih A, Lal JK. Concentrations and carcinogenic profiles of polycyclic aromatic hydrocarbons (PAHs) in groundwater of an urban site at a terai belt of North India. Int J Appl Eng Res 2014;9(1)1-8.

[19] Lawal AT. Polycyclic aromatic hydrocarbons: a review. Cogent Environmental Science 2017;3(1):1339841. https://doi.org/10.1080/23311843.2017.1339841

[20] Agency for Toxic Substances and Disease Registry (ATSDR). Toxicological Profile for Polycyclic Aromatic Hydrocarbons (PAHs). 1995. http://www.atsdr.cdc.gov

[21] U.S. Environmental Protection Agency (USEPA). Test methods for Evaluating Solid wastes: Physical Chemical Methods (SW-846) on CD-RON, No.8310, U.S. National Technical Information Service, VA., USA; 1998: 200- 230. https://www.epa.gov/hw-sw846/sw-846-test-method-8310-polynuclear-aromatic-hydrocarbons

[22] U.S. Environmental Protection Agency (USEPA). Exposure Factors Handbook Ed (Final). National Center for Environmental Assessment, Office of Research and Development, Washington DC, USA; 2011. http://cfpub.epa.gov/ncea/risk/recordisplay.cfm?deid=236252

[23] U.S. Environmental Protection Agency (USEPA). Regional Screening levels (RSLs) Table. Assessed on May 1, 2020. https://www.epa.gov/risk/regional-screening-levels-rsls-generic-tables.

[24] Doyle E, Muckian L, Hickey AM, Clipson N. Microbial PAH degradation. Adv Appl. Microbiol 2008;65:27-66.

[25] Omokpariola DO, Nduka JK. Assessment of rainwater quality from selected locations in Rivers State, Nigeria [Thesis]. Department of Pure and Industrial Chemistry, Nnamdi Azikiwe University, Awka, Nigeria 2021 (English). Accessed on April 12, 2021. 
[26] Okechukwu VU. Onwukeme VI. Source identification and risk assessment of polycyclic aromatic hydrocarbons (PAHs) and heavy metals around selected dumpsites in port harcourt and yenagoa, Nigeria. [Thesis]. Department of pure and industrial chemistry, Nnamdi Azikiwe University, Awka, Nigeria 2021 (English). Accessed on April 12, 2021.

[27] Hassan I, Kalin RM, Aladejana JA, White CJ. Potential impacts of climate change on extreme weather events in the Niger part of Nigeria. Hydrology 2020;7(1)A:19-31. https://doi.org/10.3390/hydrology7010019

[28] U.S. Environmental Protection Agency (USEPA). Test methods for evaluating Solid Waste, SW -846, 3rd ed. (USEPA, office of solid waste and emergency response, Washington, DC, November). 2016, 200-206. Accessed on $22,2021$. https://www.epa.gov/hw-sw856

[29] U.S. Environmental Protection Agency (USEPA). Regional screening levels (RISLS)- user's guide- Risk assessment. United States environmental protection agency 2017. Accessed on May 4, 2020. https://www.epa.gov/risk/regionalscreening-levels-rsls.

[30] U.S. Environmental Protection Agency (USEPA). U.S. Environmental Protection Agency. Human health evaluation manual, supplemental guidance: standard default exposure factors; USEPA: Washington, DC, USA 1991. Accessed on January 12, 2021.

https://nepis.epa.gov/Exe/ZyNET.exe/P100NQNA.TXT?ZyActionD=ZyDocument\&Client=EPA\&Index=2011+Thru+201 $5 \&$ Docs $=\& Q u e r y=\&$ Time $=\&$ EndTime $=\&$ SearchMethod $=1 \&$ TocRestrict $=$ n $\&$ Toc $=\&$ TocEntry $=\& Q F i e l d=\& Q F i e l d Y e a r=\& Q$ FieldMonth $=\& Q F i e l d D a y=\& I n t Q F i e l d O p=0 \&$ ExtQFieldOp $=0 \&$ XmlQuery $=\&$ File $=D \% 3 \mathrm{~A} \% 5 \mathrm{Czy}$ files $\% 5 \mathrm{CIndex} \% 20 \mathrm{Data}$ $\% 5 C 11$ thru15\%5CTxt\%5C00000018\%5CP100NQNA.txt\&User=ANONYMOUS\&Password=anonymous\&SortMethod=h $\% 7 C-$

\&MaximumDocuments=1\&FuzzyDegree=0\&ImageQuality=r75g8/r75g8/x150y150g16/i425\&Display=hpfr\&DefSeekPag $\mathrm{e}=\mathrm{x} \&$ SearchBack=ZyActionL\&Back=ZyActionS\&BackDesc=Results\%20page\&MaximumPages=1\&ZyEntry=1\&SeekPag $\mathrm{e}=x \& Z y P U R L$

[31] U.S. Environmental Protection Agency (USEPA). Guidelines for carcinogen risk assessment [EPA Report]. (EPA/630/P03/001F). Washington, DC: U.S; 2005a. Accessed on January 12, 2021. http://www2.epa.gov/osa/guidelines-carcinogenrisk-assessment.

[32] U.S. Environmental Protection Agency (USEPA). Supplemental guidance for assessing susceptibility from early-life exposure to carcinogens. (EPA/630/R-03/003F). Washington, DC; 2005b. Accessed on January $12,2021$. https://www3.epa.gov/airtoxics/childrens supplement final.pdf.

[33] Chen CW, Chen CF, Dong CD, Tu YT. Composition and source apportionment of PAHs in sediments at river mouths and channel in Kaohsiung Harbor, Taiwan. J Environ Monit 2012;14(1):105-15. https://doi.org/10.1039/C1EM10557D

[34] Aderonke AM, Iniaghe PO, Omotayo TA, Bello MO, Abdulkadir MD. Source analysis of heavy metals and polycyclic aromatic hydrocarbons from a popular dumpsite, Lagos State, Nigeria. JTCSA 2020;7(2): 489-504.

https://doi.org/10.18596/jotcsa.687322

[35] Tella AC, Ajayi SO, Abiola BE, Adekunle AK, Akintelu AS, Olabemiwo OM. Assessment of the levels of polycyclic aromatic hydrocarbons in wazo market topsoil, Ogbomoso, Nigeria. J Anal Environ Chem 2017;3(1):111-118.

[36] Adedosu TA, Omotayo KA, Omolola HA. Distribution, Sources and Toxicity Potentials of Polycyclic Aromatic Hydrocarbons in Soils around the Vicinity of Balogun-Birro Dumpsite of Oshogbo, Nigeria. Malaysian J Anal Sci 2015;19 (3), 636-648.

[37] Ekpete OA, Edori OS, Iyama WA. Concentrations of polycyclic aromatic hydrocarbons from selected dumpsites within port harcourt metropolis, Rivers State, Niger Delta, Nigeria. Int J Environ Sci Nat Res 2019;21(4):556066. https://doi.org/10.19080/IJESNR.2019.21.556066

[38] Agency for Toxic Substances and Disease Registry (ATSDR). Polycyclic Aromatic Hydrocarbons (PAHs): What health effects are associated with PAH exposure? Accessed on March 12, 2021. https://www.atsdr.cdc.gov/csem/polycyclicaromatic-hydrocarbons/health effects.html.

[39] Emoyan OO, Akporhonor EE, Agbaire PO, Akporido SO. Concentration Characteristic of Polycyclic Aromatic Hydrocarbons (PAHs) in Depth-Wise Soils, Sapale, Nigeria. Int Res J Public Environ Health 2015;2(6):70-79. http://dx.doi.org/10.15739/irjpeh.023 
Okechukwu et al. I Pollution investigation \& risk assessment of PAHs in soil and water

[40] Simeon EO. Distribution of polycyclic aromatic hydrocarbons in surface water of Elelenwo River, Rivers State, Niger Delta Nigeria. Int J Env Mon Anal 2020;8(2):23-26. http://doi.org/10.11648/j.ijema.20200802.11

[41] Edori OS, Iyama WA. Source identification of polycyclic aromatic hydrocarbons in water at point of effluent discharge into the New Calabar River, Port Harcourt, Rivers State, Nigeria. Int J Env Climate Change 2019;9(6):343-349. https://doi.org/10.9734/IJECC/2019/v9i630119

[42] Anyakora C, Coker H. Determination of polynuclear aromatic hydrocarbons (PAHs) in selected water bodies in the Niger Delta. African J Biotechnol 2006;5(21):2024-2931.

[43] Federal Ministry of Environment (FMEnv). Environmental Impact Assessment Decree 86, Procedural Guidelines, 1992. Published by the Federal Government Press, Lagos, Nigeria.

[44] Olayinka OO, Adedeji OH, Ipeaiyeda AR. Determination of polycyclic aromatic hydrocarbons (PAHs) on selected dumpsites in Abeokuta Metropolis, SW, Nigeria. Appl Environ Res 2015;37(3):33-48. https://doi.org/10.35762/AER.2015.37.3.3

[45] Bucheli TD, Blum F, Desaules A, Gustafsson Ö. Polycyclic aromatic hydrocarbons, black carbon, and molecular markers in soils of Switzerland. Chemosphere 2004;56(11):1061-1076. https://doi.org/10.1016/j.chemosphere.2004.06.002

[46] Shamilishvily G, Abakumov E, Gabov D. Polycyclic aromatic hydrocarbon in urban soils of an Eastern European megalopolis: distribution, source identification and cancer risk evaluation. Solid Earth 2018;9(3):669-682. https://doi.org/10.5194/se-9-669-2018

[47] Jiao H, Wang Q, Zhao N, Jin B, Zhuang X, Bai Z. Distributions and sources of polycyclic aromatic hydrocarbons (PAHs) in soils around a chemical plant in Shanxi, China. Int J Environ Res Public Health 2017;14(10),1198.

https://doi.org/10.3390/ijerph14101198

[48] Yunker MB, Macdonald RW, Vingarzan R, Mitchell RH, Goyette D, Stephanie S. PAHs in the Fraser River basin: a critical appraisal of PAH ratios as indicators of PAH source and composition. Organic Geochem 2002;33(4):489-515. https://doi.org/10.1016/S0146-6380(02)00002-5

[49] Zhang G, Pan Z, Wang X, Mo X, Li X. Distribution and accumulation of polycyclic aromatic hydrocarbons (PAHs) in the food web of Nansi Lake, China. Environ Mon Ass 2015;187(4):1-12. https://doi.org/10.1007/s10661-015-4362-4

[50] Zhang W, Zhang S, Wan C, Yue D, Ye Y, Wang X. Source diagnostics of polycyclic aromatic hydrocarbons in urban road runoff, dust, rain and canopy through fall. Environmental pollution. 2008;153(3):594-601. https://doi.org/10.1016/j.envpol.2007.09.004

[51] Dominguez C, Sarkar SK, Bhattacharya A, Chatterjee M, Bhattacharya BD, Jover E, et al. Quantification and source identification of polycyclic aromatic hydrocarbons in core sediments from Sundarban Mangrove Wetland, India. Arch environ Contam Toxicol, 2010;59(1):49-61. https://doi.org/10.1007/s00244-009-9444-2

[52] Ojaniyi OF, Okoye PAC, Omokpariola DO. Heavy metals analysis and health risk assessment of three fish species, surface water and sediment samples in Ogbaru Axis of River Niger, Anambra State, Nigeria. Asian J Appl Chem Res. 2021;9(1):64-81. https://doi.org/10.9734/AJACR/2021/v9i130205

[53] Olawoyin R, Grayson RL, Okareh OT. Ecotoxicological and epidemiological assessment of human exposure to polycyclic aromatic hydrocarbons in the Niger Delta, Nigeria. Toxicol Environ Health Sci 2012;4(3):173-185.

https://doi.org/10.1007/s13530-012-0133-6

[54] Williams PL, James RC, Roberts SM. Principles of toxicology environmental and industrial applications, 2nd ed. United States: Wiley-Interscience Publishers; 2014, 1-495.

[55] U.S. Environmental Protection Agency (USEPA). Risk Assessment Guidance for Superfund Volume I: Human Health Evaluation Manual (Part E, Supplemental Guidance for Dermal Risk Assessment); USEPA: Washington, DC, USA; 2004. https://nepis.epa.gov/Exe/ZyNET.exe/P1001A65.TXT?ZyActionD=ZyDocument\&Client=EPA\&Index=2000+Thru+2005\&Docs=\&Query

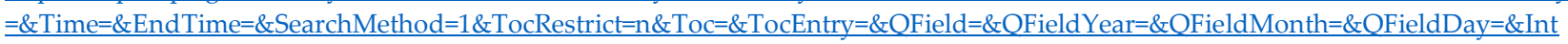
QFieldOp $=0 \&$ ExtQFieldOp $=0 \&$ XmlQuery $=\&$ File $=$ D\%3A \%5Czyfiles $\% 5$ CIndex $\% 20$ Data $\% 5$ C00thru05\%5CTxt $\% 5$ C00000015\%5CP1001A 65.txt\&User $=$ ANONYMOUS\&Password $=$ anonymous\&SortMethod $=\mathrm{h} \% 7 \mathrm{C}$ -

\&MaximumDocuments=1\&FuzzyDegree=0\&ImageQuality=r75g8/r75g8/x150y150g16/i425\&Display=hpfr\&DefSeekPage=x\&SearchBac $\underline{\mathrm{k}=Z y \text { ActionL\&Back=ZyActionS\&BackDesc=Results\%20page\&MaximumPages }=1 \& Z y \text { Entry }=1 \& S e e k P a g e=x \& Z y P U R L}$

[56] U.S. Environmental Protection Agency (USEPA). Toxics Release Inventory: Public Data Release Report 2001. Accessed on Feb 24, 2021 
https://19january2017snapshot.epa.gov/sites/production/files/documents/2001_national_analysis executive_summary. pdf.

[57] Knafla A, Phillipps KA, Brecher RW, Petrovic S, Richardson M. Development of a dermal cancer slope factor for benzo[a]pyrene. Regul Toxicol Pharmacol 2006;45(2):159-168. https://doi.org/10.1016/j.yrtph.2006.02.008

[58] Chen C, Tang Y, Jiang X, Qi Y, Cheng S, Qiu C, et al. Early postnatal benzo(a)pyrene exposure in sprague-dawley rats causes persistent neurobehavioral impairments that emerge postnatally and continue into adolescence and adulthood. Toxicol Sci 2012;125(1):248-261. http://dx.doi.org/10.1093/toxsci/kfr265

[59] Iwegbue CM, Obi G, Aganbi E, Ogala JE, Omoleomo O, Omo-Irabor OO, Martincigh BS. Concentrations and health risk assessment of polycyclic aromatic hydrocarbons in soils of an urban environment in the Niger Delta, Nigeria. Toxicol Environ Health Sci 2016;8(3):13530-016. https://doi.org/10.1007/s13530-016-0279-8

[60] Centers for Disease Control and Prevention (CDC). Fourth national report on human exposure to environmental chemicals. 2009. Accessed on Feb 24, 2021. https://www.cdc.gov/exposurereport/pdf/fourthreport.pdf.

[61] Marsalek J, Diamond M, Kok S, Watt WE. Threats to sources of drinking water and aquatic ecosystem health in Canada, National Water Research Institute (NWRI) Scientific Assessment Report Series No.1, Environment Canada, Ch. 11, 2001; 47-50. https://publications.gc.ca/site/eng/9.558191/publication.html\#shr-pg0

[62] Ramesh A, Walker SA, Hood DB, Guillen MD, Schneider K, Weyand EH. Bioavailability and risk assessment of orally ingested polycyclic aromatic hydrocarbons. Int J Toxicol 2004;23(5):301- 333. https://doi.org/10.1080/10915810490517063

[63] Prabhukumar G, Pagilla K. Polycyclic aromatic hydrocarbons in urban runoff - sources, sinks and treatment: A review [Dissertation]. Department of Civil, Architectural \& Environmental Engineering: Illinois Institute of Technology, Chicago, IL;2010 (English).

[64] Gardner RON. Overview and characteristics of some occupational exposures and health risks on offshore oil and gas installations. Annals Occup Hyg. 2003;47(3):201-210. http://doi.org/10.1093/annhyg/meg028. 